\title{
Interdisciplinarna metoda istraživanja, zaštita i prezentacija stećaka u kontekstu ikonoloških studija
}

IVANKA RIBAREVIĆ-NIKOLIĆ

Montréal

E-pošta: ivanka_rn@outlook.com

\author{
UDK: $726.825: 719$
7.034 .1 \\ UDK: $726.825: 719$ \\ Izvorni znanstveni rad \\ Primljeno: 2. ožujka 2020 \\ Prihvaćeno: 10. lipnja 2020
}

\section{Sažetak}

Istaknuta je važnost ikonografske i ikonološke analize reljefnih prikaza na stećcima. Da bi takva istraživanja bila moguća, neophodna je tehnička, grafička i foto-dokumentacija s neizostavnom naznakom orijentacije spomenika. Slijedeći načela teorije o kopiranju u srednjem vijeku, uz izvore koje donosi Legenda aurea, te usporedbom s prikazima arhitekture u Beatusovu komentaru Apokalipse, ukazano je na moguće značenje motiva podignute desne ruke s koncentričnim krugovima "vojvodskih figura", samostalnoga motiva ruke s mačem i motiva arkada s potkovičastim lukovima.

Ključne riječi: dokumentacija; ikonologija; Radimlja; Zlatna legenda; Beatus.

* Sažetak predavanja izložen je na skupu: "Stećci u 21. stoljeću - nove spoznaje i mogućnosti interpretacije", održanom 17. listopada 2019. u Mostaru. 
Ivanka Ribarević-Nikolić - Interdisciplinarna metoda istraživanja...

\section{Uvod: metoda istraživanja i teme}

Ovaj osvrt nosi složeni koncept višeslojne tematike, koji je u čvrstoj idejnoj metodičkoj sprezi i ne izlazi iz konteksta tema od bitne važnosti za istraživanje stećaka. Prije svega mislimo na ikonografski koncept tumačenja prikaza na stećcima, a zatim na njihovo viđenje $\mathrm{u}$ kontekstu ikonologije, u mjeri u kojoj nam je to bilo moguće na ovoj razini istraživanja.

Pojasnimo, obje metode, ikonografija i ikonologija u osnovi istraživanja "polaze od istoga ishodišta, ali imaju različite ciljeve. Ikonografija je metoda deskripcije, a ikonologija metoda interpretacije. Ikonografija prepoznaje, imenuje, klasificira, katalogizira i opisuje sadržajne elemente 'slike', dok ih ikonologija objašnjava, povezuje i prevodi u koncepte i postavlja u kontekste. Također, ikonologija pokušava sagledati ulogu koju je umjetničko djelo imalo u vremenu i prostoru u kojemu je nastalo i ujedno nastoji rekonstruirati percepciju sadržaja kako ga vidi gledatelj kojemu je bilo namijenjeno".1

Nadalje, važno je istaknuti da su podloga za ikonografsku analizu pisani tekstovi, a također i likovna djela nastala u prethodnim periodima. Upravo ta djela mogla su poslužiti kao predlošci ili uzori. Rijetki su primjerci gdje je umjetnik, slikar ili kipar, samostalno "transportirao tekstualni sadržaj u vizualni oblik". Traženje, usporedbom, najranijega uzorka, odnosno prototipa, čini osnovu ikonografske analize. Tradicija razmjene i prenošenja ikonografskih ideja unutar kruga radionice ili obrta, izvan granica vremenskoga ili limitiranoga prostornog određenja, reflektira izvore nekih motiva ili kompozicija u dalekoj prošlosti i "proteže se kroz više povijesnih slojeva i oprečnih kulturnih krugova". Znamo da kršćanska ikonografija preuzima motive iz poganske ikonografije, ne samo neposredno iz rimske, nego također i grčke. Tako možemo sagledati "liniju kontinuiteta povijesti umjetnosti". Nadalje, također prema Radovanu Ivančeviću, "iskazivanje verbalnog u vizualni okvir likovnog", može biti izraženo kroz pet ikonografskih metoda, koje se sukcesivno javljaju. "Govor simbola", tipičan za ranokršćansko razdoblje, te "simboličke scene" koje se javljaju i traju istovremeno sa simbolima bivajući postupno dominantnije idući prema kraju perioda. Obje ove metode nastavljaju se u predromanici. "Metoda redukcije" ili reducirane scene, ute-

1 Marina Vicelja-Matijašıć, Ikonologija. Kritički prikaz povijesti metode, Rijeka, 2013., str. 7. 
meljena u ranokršćanskoj umjetnosti, postaje dominanta romaničke umjetnosti. "Narativna metoda" razvija se u gotici 13. i osobito 14. stoljeća kao izraz okretanja k realnosti gotičkoga humanizma. Kasnije, "metoda simulacije" iskazuje renesansni otklon od religioznoga ka "svjetovnome".2

U umjetnosti stećaka možemo pratiti "simultanost" govora simbola, gdje prioritet nije događaj (križ koji ukazuje na čin Raspeća), nego značenje toga događaja. Ovo treba imati na umu svaki put kada se iznese konstatacija da figurativni motiv prikaza Raspeća na stećcima nije zastupljen. Potvrdu prve četiri teoretske postavke, odnosno ikonografske metode, sagledavamo na reljefnim prikazima umjetnosti stećaka, zaključno s periodom procvata te umjetnosti osobito u 15. stoljeću i početaka njezina gašenja krajem toga stoljeća. Primjeri koji su odabrani u ovome članku izravna su potpora većini navedenih iskaza, uz naputak da ova složena tematika zahtijeva daljnja produbljena istraživanja, kojima bi bila obuhvaćena znatno šira grupa spomenika.

Slijedeći navedene ikonografske smjernice posvećena je pozornost izabranim motivima kruga, spirale, vinove loze, osvrćući se na njihovo dugo trajanje. Ujedno ukazano je na transformaciju njihova, ishodišno poganskoga, značenja u novom povijesnom i kulturnom ikonografskom okviru (T. I., II.).

Glavna tema istraživanja usmjerena je na ikonografsko značenje i ikonološko tumačenje motiva podignute desne ruke $s$ frontalno okrenutim dlanom i pridruženim koncentričnim krugovima "vojvodskih figura", odnosno ratnika, na nekropoli Radimlja (Stolac), osobito onih spomenika na kojima su ovi ratnici prikazani s djecom (T. IV., V., VI.).

Tijekom rada na ovoj temi, konzultirajući znanstvene radove kako opće tematike, tako i specifične problematike medievalne umjetnosti, sagledali smo nešto širu ikonografsku problematiku. Na osnovi dosadašnjih istraživanja stećaka, gotovo stoljetnoga trajanja, te iskazanih često oprječnih mišljenja prisutnih i danas, jasno je da znanstvenim odgovorima mogu doprinijeti samo ciljna interdisciplinarna istraživanja i analogna dokumentacija objedinjena u centralnoj

2 Radovan Ivančević, "Uvod u ikonologiju", u: AnĐelko Badurina (ed.), Leksikon ikonografije, liturgike i simbolike zapadnog kršćanstva, Zagreb, 1979., str. 15-16, 51-52. 
Ivanka Ribarević-Nikolić - Interdisciplinarna metoda istraživanja...

akademskoj ustanovi. ${ }^{3}$ Isto viđenje dijele općenito znanstvenici čija su domena istraživanja stećci, odnosno medievalni period u kojemu ovi spomenici nastaju i traju. ${ }^{4}$

Svakako, važno je povijesno-kulturno nasljeđe sredine, u užem zemljopisnom određenju kulturnoga pejzaža, na kojem se razvija umjetnost stećaka, podjednako kao i uplivi kulturnih strujanja europskoga srednjovjekovlja. ${ }^{5} \mathrm{U}$ istom kontekstu razmišljanja željeli bismo istaknuti viđenje iskazano u radu Đure Baslera 1966. godine, u kojemu autor govori o uplivima romaničke i gotičke umjetnosti na stećke. Autor naglašava da većinski dio motiva na stećcima "u formalnom i sadržajnom pogledu podsjeća na romaničke uzore", naglašavajući da simbolički prikazi, "kao što su rozete, sunce, mjesec, stilizirani križevi i drugi motivi religioznog karaktera vuku neposredno svoje podrijetlo iz romaničke umjetnosti". Nadalje, autor naglašava da prevladavajući romanički "religiozno-mistični karakter" motiva na stećcima postupno biva oslabljen i očituje se "prodor racionalizma koji se vizualno manifestirao u virtuoznom konstruktivitetu i realizmu gotike". Autor zaključuje da "to slabljenje prvobitnih principa odražavaju izrazito gotički komponirani spomenici iz 15. st." kao što je "stećak iz Zgošće", gdje su, nekada ishodišno simbolički prikazi ovdje "čini se, postali već realistička umjetnička naracija sa zaboravljenim prvobitnim značenjem motiva". ${ }^{6}$

Ema Mazrak, u izvanrednoj i elaboriranoj studiji, posvećuje stećku iz Zgošće iznimnu pozornost, analizirajući sve ukrašene strane ovoga bogato dekoriranoga spomenika i akcentirajući ikonografske teme

3 Ivanka Ribarević-Nikolić, "Međunarodni multidisciplinarni centar za istraživanje stećaka u prostoru i vremenu njihove pojavnosti i njihova trajanja sa sjedištem u Mostaru: prijedlozi i promišljanja", u: Mostariensia, 21, Mostar, 1/2017., str. 39-67.

4 Ivan Alduk, "Stećci u kontekstu europskog i našeg srednjovjekovlja", u: Stećci, katalog izložbe 4. rujna - 2. studenog 2008., Zagreb, 2008., str. 44-55. Autor daje sažet i cjelovit pregled složene problematike umjetnosti stećaka u lokalnome i globalnome kontekstu srednjovjekovlja. Ujedno, citira i autore koji su ukazali na potrebu dokumentiranja kako samih spomenika, među kojima, kako Alduk zaključuje, "ne postoje dva potpuno identična", tako i topografskoga dokumentiranja nekropola unutar okvira onodobnoga povijesnog krajobraza.

5 Nada Miletić, Stećci, Beograd - Zagreb - Mostar, 1982., str. 21-24, 97-100.

6 Đuro Basler, "Stećci", u: Enciklopedija likovnih umjetnosti, sv. 4, JLZ, Zagreb, 1966., str. 320. 
Apokalipse. Ujedno, autorica nam zorno pokazuje da jedino cjelovita analiza prikaza na svim stranama jednoga spomenika, može ukazati na logički slijed likovne kompozicije datoga spomenika i pojasniti je na nama danas razumljivoj razini.?

Spominjući temu Apokalipse ukazujemo na moguće tumačenje astroloških motiva na stećcima, osobito kada su oni dio složenije kompozicije. $^{8}$

To je tema koja izaziva znatnu pozornost znanstvenika i ujedno odražava oprječnosti u iskazanim mišljenjima. Ovaj sažet osvrt pridružujemo postojećim hipotezama. Nadamo se da će izazvati pozornost, kako bi u budućem istraživanju ova ideja mogla biti valorizirana. Ujedno, na ovom primjeru akcentirana je neophodnost interdisciplinarnog istraživanja.

Pozivamo se na tematiku astrologije, odnosno na članak Krešimira Kužića, "Kamik i zvijezde" gdje autor analizira forme i poziciju prikazanih astroloških znakova, odnosno rozeta - zvijezda koje, kako imaju različiti broj "zraka" ("krakova"), zapravo nose simbolički prikaz planeta poput Jupitera, Venere, Marsa, Saturna, uz poznate nam prikaze sunca i mjeseca. ${ }^{9}$

Drugi rad pod naslovom "The Occult Middle Ages" (Okultni srednji vijek) čiji autor Peter J. Forshaw posvećuje jedno poglavlje astrologiji u srednjem vijeku, dajući sažeti povijesni pregled ove znanosti, koja je sredinom 13. stoljeća bila uključena u standardni filozofski kurikulum sveučilišta zapadne Europe kao dio quadriviuma, zajedno s matematikom, glazbom i geometrijom. Napomenimo, astrologija je od 15. stoljeća bila povezana i s medicinom. ${ }^{10}$

7 Ema Mazrak, "Stećak sljemenjak iz Donje Zgošće kod Kaknja - Novo ikonografsko tumačenje", u: Bosna franciscana, časopis Franjevačke teologije, 36, Sarajevo, 2012., str. 99-132.

8 AnĐelko Badurina (ed.), "Apokalipsa", u: Leksikon ikonografije, liturgike i simbolike zapadnog kršćanstva, Zagreb, 1979., str. 120-126. Apokalipsa je prihvaćena kao kanonska knjiga već od 3. stoljeća. Ova je tema ikonografski razvijena u Zapadnoj Crkvi, a u 14. stoljeću biva prihvaćena kao kanonska knjiga u Istočnoj Crkvi.

9 Krešimir Kužıć, "Kamik i zvijezde", u: Stećci, katalog izložbe, 4. rujna - 2. studenog 2008., Zagreb, 2008., str. 130-137.

10 Peter J. Forshaw, "The Occult Middle Ages", u: Christopher Partridge (ed.), The Occult World, New York, 2015., str. 35-36. Važno je napomenuti da 
Ivanka Ribarević-Nikolić - Interdisciplinarna metoda istraživanja...

Od važnosti je, za ideju koju akcentiramo pozivajući se na citirani članak, knjiga Liber Introductorius maior, koja je prevedena na latinski 1133. godine, a čiji je autor Abu Mashar (787.-886.), poznat pod latinskim imenom Albubasar. Knjiga je izazvala veliku pozornost kako kršćanskih, tako i hebrejskih teologa. Ideja (kronosofska teorija) da određeni planeti, a osobito oni najsporijega kretanja, kao Jupiter i Saturn, kada se pojave zajedno na nebu, djeluju na mnoga zemaljska događanja, poput jačanja ili pada pojedinih vladara ili religija, pojave ratova ili kuge. Upravo ovakva astrološka predviđanja inicirala su ideju da je moguće izračunati, odnosno astrološki predvidjeti drugi Kristov dolazak (Apokalipsa).

Ukazujemo da je bezuvjetno poznavanje astrologije, kao što je to nesumnjivo očitovano u spomenutom radu Krešimira Kužića, potrebno usuglasiti s postojećim europskim medievalnim spoznajama i teorijama, a zatim ta zapažanja interpretirati u duhu medievalnoga razmišljanja, za što je podjednako neophodno poznavanje kršćanske ikonografije. Takvo interdisciplinarno istraživanje, vjerujemo, može ukazati na drugačija tumačenja o značenju astroloških simbola na stećcima, čini se osobito unutar složenoga, spomenutoga, tumačenja Apokalipse.

Napominjemo da u ovome radu nismo posvetili pozornost natpisima, iako su oni prisutni na nekim od spomenika koje obrađujemo. Ukazujemo na zaključke Dubravka Lovrenovića da "eshatološke formule ne govore u prilog spekulaciji da je dualizam, prije nego trinitarizam, rukovodio sustav vjerovanja bosanskog srednjovjekovnog stanovništva. Naprotiv, ukupna kršćanska sepulkralna epigrafika u najmanju ruku svjedoči o jednoj kršćanskoj doktrini - doktrini budućeg uskrsnuća". ${ }^{11}$

Mišljenja smo da su u ovome trenutku naše spoznaje nedostatne, što je uvjetovano limitiranim pristupom ili nedostatkom relevantne dokumentacije o stećcima. ${ }^{12}$

su neki od važnih radova grčkih i rimskih filozofa vezani za astrologiju sačuvani u arapskom prijevodu, da bi, zajedno s radovima arapskih filozofa, bili prevedeni na latinski. https://www.academia.edu/10048161/The_Occult_ Middle_Ages (14.2.2020.).

11 Dubravko Lovrenović, "Epitafi - knjige života", u: Stećci, katalog izložbe, 4. rujna - 2. studenog 2008., Zagreb, 2008., str. 210.

12 Potvrda ovome iskazu jest značajan doprinos općim spoznajama o rasprostranjenosti, broju i razini očuvanosti stećaka odabranoga područja, iska- 
Tomu pridružujemo i nedovoljno poznavanje povijesno-kulturnoga okvira, odnosno nedostatak prikladno dokumentirane spomeničke baštine arhitektonske plastike kako ranokršćanske, tako i medievalne, što je po našem uvjerenju iznimno važno kako bi pojavnost ikonografije stećaka mogla biti cjelovitije sagledana. Upravo zbog toga odabrani su primjeri (T. I., sl. 1, 2) kao potkrjepa ovome razmišljanju. Podjednake je nezavidne razine mogućnost analize i pristupa informacijama arhitektonskih sakralnih spomenika na cjelovitoj i pristupačnoj dokumentarnoj razini. ${ }^{13}$

To ujedno uvjetuje limitiranost provođenja znanstvene povijesne interpretacije razvoja sakralne arhitekture razdoblja koji prethodi formiranju kulture stećaka i sakralne arhitekture koja im je istovremena. ${ }^{14}$

zan rezultatima istraživanja na terenu, gdje autorica Edita Vučić ukazuje na neophodnost korekcije i dopune postojećeg pregleda nekropola stećaka. Ujedno izražena je potreba primjene suvremenih metoda dokumentiranja i prezentacije dokumentacije, te ujedno istaknuta i neophodnost formiranja specijalizirane institucije za istraživanje stećaka. EdITA Vučić, Kasnosrednjovjekovne nekropole stećaka zapadne Hercegovine, (doktorski rad), Sveučilište u Zagrebu, Filozofski fakultet, Zagreb, 2018. http://darhiv.ffzg.unizg.hr/id/ eprint/10760/1/Vucic_Edita.pdf (14. 2. 2020.). Također, svakako je doprinos spoznajama i monografska obrada pojedinih nekropola ili područja, poput rada Adis Zilić, Stećci Podveležja, Mostar, 2016.

13 Ukazujemo na iznimnu važnost dokumentarnih smjernica i ciljnih zadataka međunarodnoga projekta CARE - Corpus architecturae religiosa eeuropeae (IV-X saec.) koji obuhvaća sve europske kasnoantičke i ranosrednjovjekovne crkvene građevine, ujedno sagledavajući ideološko, kulturno, socijalno i ekonomsko značenje crkve u danome razdoblju. MiLjenko Jurković - Gian Pietro Brogiolo, "Corpus architecturae religiosae europeae (IV-X saec.)", u: Hortus Artium Medievalium, Journal of the International Research Center for Late Antiquity and Middle Ages, 18, Zagreb - Motovun, 2012., https://ffzg.academia.edu/MiljenkoJurkovic (14. 2. 2020.).

14 Neophodno je istaknuti iznimnu važnost novih nalaza sakralne arhitekture i nalaza grobova što je rezultat recentne revizije arheoloških istraživanja na lokalitetu Crkvina u Zavali u Općini Ravno, kojima je rukovodila Snježana Vasilj, čije izvješće vrlo sažeto citiramo. Ovi su nalazi izvanredno važan znanstveni doprinos spoznajama o povijesti crkvene arhitekture na današnjem prostoru Hercegovine. Istraženi su ostatci crkve sv. Petra za koje se veže kamena plastika predromaničke i romaničke provenijencije, koja se čuva u Muzeju Hercegovine u Trebinju, te osobito vrijedni arhitektonski slojevi ispod ostataka crkve sv. Petke. Ovdje su u drugome sloju nađeni ostatci crkve s potkovičastom apsidom iz 11. stoljeća i u trećem sloju ostatci trolisne crkve s predvorjem vjerojatno iz 9. stoljeća. Snježana VAsıLJ, "Arheološki lokalitet Crkvina u Zavali, Općina Ravno, revizija istraživanja iz 1957. godine", u: Hercegovina, 4, Mostar - Zagreb, 2018., str. 49-86. 
Ivanka Ribarević-Nikolić - Interdisciplinarna metoda istraživanja...

S ciljem da se približimo kriterijima, načinu viđenja i načinu "čitanja" simbola medievalnoga naručitelja umjetničkoga djela i umjetničkoga izričaja kreatora umjetnika, a zadržavajući kritičku analitičnost suvremenoga istraživača, posegnuli smo za popularnim i cijenjenim medievalnim izvorom Legenda aurea - Zlatna legenda koja je poput Biblije tekstualni izvor ikonografskih tema. ${ }^{15}$ Od iznimne su važnosti tumačenja događaja i života svetaca u ovoj, nadasve popularnoj medievalnoj knjizi iz 13. stoljeća, koja je bila dobro poznata i u krajevima rasprostranjenosti stećaka, a i znatno šire. ${ }^{16}$

Upravo informacije o životu svetaca koje donosi Legenda aurea uz likovni prikaz na fresci iz Siene, dale su nam osnovu za novo viđenje ikonografskoga tumačenja samostalnoga motiva ruke ležerno savijene u laktu koja drži mač, povezujući taj motiv sa sv. Mihovilom.

Presudan za naša inicijalna istraživanja ikonografske poruke podignute desne ruke s pridruženim koncentričnim krugovima "ratnika s djecom", odnosno "vojvodskih figura" iz Radimlje, bio je znanstveni rad Wolfganga Loseriesa o relikvijama i freskama kasnosrednjovjekovne Siene, gdje su prikazana dva važna događaja vezana za Rim, a koje opisuje Legenda aurea. ${ }^{17}$

Autor je posvetio pozornost likovnim prikazima na freskama koji su tematski vezani za čuvenu čudesnu procesiju protiv kuge pape Grgura I. Velikog (590.-604.) u Rimu. Upravo navedeni likovni prikazi na freskama u Sieni iskazuju važnost štovanja relikvija u borbi protiv kuge. Osobito važan i indikativan za naša istraživanja bio je osvrt W. Loseriesa na povijesnu važnost jedinstvenoga ikonografskog prikaza

15 Jacobus de Voragine, Zlatna legenda ili Štiva o svecima, sv. 1,2, preveo s latinskoga izvornika Stjepan Pavić, Zagreb, 2015.; R. IvančEvić, "Uvod u ikonologiju", str. 21.

16 Zlatna legenda nije bila prevedena, ali je bila poznata u izvorniku o čemu svjedoči katalog inkunabula u Hrvatskoj, a susreće se i u samostanskim knjižnicama u Rijeci, Zagrebu, Kamporu, Dubrovniku, Karinu, Bolu na Braču. MARKO GRČIĆ, "Jacobus de Voragine i Legenda aurea", u: Zlatna legenda ili Štiva o svecima, sv. 2, preveo s latinskoga izvornika Stjepan Pavić, Zagreb, 2015., str. 485-497.

17 Wolfgang Loseries, "Presentation of Relics in Late Medieval Siena The Cappella delle Reliquie in Siena Cathedral", u: JAMEs RoBinson - Lloyd DE Beer - Anna Harnden (ed.), Matter of Faith: An Interdisciplinary Study of Relics and Relics Veneration in the Medieval Period, The British Museum, London, 2014., str. 56-65. 
Bogorodice s podignutom desnom rukom, čija je slika rađena temperom na drvu i poznata je pod imenom Madonna di Santa Maria in Aracoeli koju je prema predaji slikao sv. Luka. Pretpostavlja se da je naslikana u trećoj četvrtini 11. stoljeća i čuva se u istoimenoj franjevačkoj crkvi u Rimu. Ova slika Bogorodice nošena je u spomenutoj procesiji Grgura Velikog. Na zagovor Bogorodice i uz pomoć sv. Mihovila kuga je nadvladana.

Također specifičan fresko-prikaz "proricanja Augustu" rođenja Kristova, u kojemu prepoznajemo simbol koncentričnih krugova, drugi je važan element za naša istraživanja i ikonografska tumačenja navedenih motiva iz Radimlje (T. V.), gdje dva odvojena simbola, desna ruka Bogorodice zagovornice i motiv koncentričnih krugova, postaju jedan složeni simbol.

Povijesno, potvrđena je povezanost Radimlje i Dubrovnika (T. IV.) izravnim trgovinskim vezama. ${ }^{18}$ Nadalje, Dubrovnik je, kao važna morska luka i međunarodno trgovačko središte, bio povezan s Rimom, koji je jedno od najvažnijih hodočasničkih središta Europe. Ujedno grad je bio izložen brojnim naletima epidemije kuge, koje su dolazile uglavnom s mora, ali i s kopna. Možemo pretpostaviti, ali ne i tvrditi, da je ova kužna bolest imala utjecaja i na populaciju Radimlje, preciznije na članove obitelji Hrabrena-Miloradovića, koji su prikazani kao "vojvodske figure", odnosno ratnici s djecom. ${ }^{19}$

Važno je naglasiti da je u istoj, već spomenutoj crkvi Santa Maria in Aracoeli u Rimu, u kojoj se čuva istaknuta slika Bogorodice, za-

18 Dubravko Lovrenović, "Topografija stećaka u BiH - gradovi mrtvih", u: Stećci, katalog izložbe, 4. rujna - 2. studenog 2008., Zagreb, 2008., str. 140-195.

19 Zlata Blažina Tomić, Kacamorti i kuga, Utemeljenje i razvoj zdravstvene službe u Dubrovniku, HAZU Dubrovnik, 2007., str. 1-295; Zlata BlažınA Tomić - Vesna BlažIna, Expeling the Plague, The Health Office and the Implementation of Quarantine in Dubrovnik, 1377-1533, McGill-Queens University Press, Montreal, 2015., str. 1-362. Uz glavnu povijesnu temu, vezanu uz formiranja i djelatnosti medicinske službe u Dubrovniku, u ovim radovima nalazimo značajne arhivske podatke koji se izravno odnose na veze Dubrovačke Republike, Bosne i Huma, Novog (Herceg Novi), te ocrtavaju ekonomski, kulturni i religijski okvir datoga perioda. Donacije i zavjetni darovi, kao što je to uobičajeno u europskim gradovima zabilježene su i u Dubrovniku. Poznata je kronologija epidemija kuge i kužnih bolesti koje nisu bile dijagnosticirane kao kuga. Na žalost, nemamo podatke o postojanju kužnih bolesti ili epidemija u Hercegovini, odnosno Radimlji u istome periodu. 
Ivanka Ribarević-Nikolić - Interdisciplinarna metoda istraživanja...

govornice - advocata, sahranjena 1478. bosanska kraljica Katarina Kosača. $^{20}$

Činjenica da je bosanska kraljica sahranjena u ovoj značajnoj franjevačkoj rimskoj crkvi, vjerujemo mogla je imati upliva na popularnost, već poznatoga i arheološki potvrđenoga običaja, sahranjivanja znamenitih osoba u interijeru crkava i na područjima rasprostranjenosti kulture stećaka.

Istovremeno konzultirajući znanstvene radove o teoriji kopiranja i uporabi knjige modela (exemplum) pokušali smo, na primjeru spomenutoga odabranog reljefa podignute desne ruke frontalno okrenutoga dlana s pridruženim koncentričnim krugovima "vojvodskih figura" Radimlje (T. V., VI.), pojasniti pojam "kreativne kopije" i ukazati na njezino moguće ikonološko značenje. ${ }^{21}$ Istaknimo da su uobičajeno korišteni termini, odnosno pojmovi "kopija", "citat" i "kreativna kopija" u literaturi koju citiramo.

Studiranje znanstvenih radova tematski vezanih za medievalne principe kopiranja i višeznačnoga odnosa originala i kopije, inicirali su našu bolju informiranost o postojanju višebrojnih manuskripta Beatusova komentara Apokalipse, čiji original potječe iz 8. stoljeća. Upravo jedna rana kopija Beatusa (Sl. 2), istovjetna stilu i kompozi-

20 Claudia Bolgia, Reclaming the Roman Capitol: Santa Maria in Aracoeli from the Altar of Augustus to the Franciscans, c. 500-1450., New York, 2017. i recenzija "Review" by Emily E. Graham u: The Medieval Review (8. 11. 2019.) BMCR, Bryn Mawr College, https://scholarworks.iu.edu/journals/index.php/ tmr/article/view/28839 (14. 2. 2020.); Nina ČulJak, "Križevi u Sveći (Drežnica kod Mostara) kroz prizmu Arbuthnotova putopisa", u: Suvremena pitanja, časopis za prosvjetu i kulturu, Mostar, 2018., str. 117, sl. 5, donosi prijepis teksta $s$ izvorne nadgrobne ploče Katarine Kosača iz vremena dok je još bio in situ, prema G. Palatino iz 1550. godine.

21 Robert W. Scheller, Exemplum, Model book Drawings and the Practice of Artistic Transmission in the Middle Ages (ca 900-ca 1450), Amsterdam, 1995., str. 1-434; SARAH BLICK, "Exceptions to Krauthammer's Theory of Copying", $\mathrm{u}$ : Visual Resources Special Issue: Copying in Medieval Art, XX, 2-3, Routledge, 2004., str. 123-142; Monika E. Müller, "The Use of Models in medieval Book Painting, Introduction", u: Monika E. Müller (ed.) The Use of Models in medieval Book Painting, Cambridge, 2014., str. XI-XXX. Valja naglasiti da su se autori koji su istraživali umjetnost stećaka, kao Đ. Basler i Š. Bešlagić, naravno osvrnuli na principe kopiranja. Mi akcentiramo u ovome članku teoretske i specifično tematske studije, čija smo načela i terminologiju aplicirali na odabranim primjerima. 
ciji originala, dovela nas je do zaključka i predloženoga tumačenja ikonografskog značenja motiva arkada s potkovičastim lukovima (T. III.) u kontekstu Apokalipse. ${ }^{22}$

Ovaj opširni, faktografski koncipirani uvod, dat je s ciljem da se okvirno prezentira tematika koja čini osnovu ovoga članka, a iskazana je u naslovu rada i koja, neminovno, ima izvjesnu razinu složenosti. Ta je složenost uvjetovana zahtjevnošću tumačenja motiva na stećcima u čije značenje pokušavamo proniknuti. Osobitosti povijesnoga vremena nastanka stećaka, vjera i važnost relikvija, odnosno važnost poruke simbola koji govore o vjeri i njezinu viđenju dio su filozofije življenja medievalnoga čovjeka. Ta filozofija može biti iskazana riječima "vjera u čudo i čudo vjere". 23

\section{Stećci: dokumentacija}

Proces ikonografskih istraživanja reljefnih prikaza na stećcima te općenito zaštita stećaka, njihova konzervacija, muzeološka i edukacijska prezentacija, te prezentacija u stručnom ili popularnom tisku, neumitno zahtijevaju, usklađen, sveobuhvatan i lako čitljiv način dokumentiranja.

Želimo istaknuti važnost ustanovljenja jedinstvenoga shematskog načina dokumentiranja gdje bi elektronički pristupačni "modeli" dali mogućnost autorima, istraživačima ili dokumentaristima odabir i brzu aplikaciju shematskoga crteža - šablona koji bi, kao elementarni dokumentarni znak, nosio podatke o formi, odnosno okvirnim proporcijskim omjerima (ploča, sanduk, visoki sanduk, sljemenjak

22 Peter K. KLein, "The Role of Prototypes and Models in the Transmission of Medieval Picture Cycles: The Case of the Beatus Manuscripts", u: MonikA E. Müller (ed.) The Use of Models in medieval Book Painting, Cambridge, 2014., str. 1-28. Takoder, John Williams-Therese Martin, Vision on the End in Medieval Spain, Catalogue of Illustrated Beatus Commentaries on the Apocalypse and Study of the Geneva Beatus, Amsterdam University Press, 2017., str. 1-292. Ovaj izvanredni bogato ilustrirani katalog daje pristup i mogućnosti analize Beatusova komentara apokalipse i ujedno, po našem dubokom uvjerenju, daje osnovu za interpretaciju još nekih ikonografskih tumačenja, što je hipotetski spomenuto u našem članku. Elektronički pristup (open access), https://www.aup.nl/en/book/9789462980624/visions-of-the-end-in-medieval-spain (14. 2. 2020.).

23 ŽElJKa Čorak, "Pogovor Zlatnoj legendi", u: Zlatna legenda ili Štiva o svecima, sv. 2, preveo s latinskog izvornika Stjepan Pavić, Zagreb, 2015., str. 477-483. 
Ivanka Ribarević-Nikolić - Interdisciplinarna metoda istraživanja...

trokutnog ili lučnog zabata, križ, dječji nadgrobnik itd.), ukazivao na oblik bočnih ploha (pravokutne, trapezoidne), na vrstu postolja, te determinirao orijentaciju spomenika.

Ovakav grafički prikaz bio bi upotpunjen fotografijom, po mogućnosti svih strana spomenika is naznakom datuma snimanja. ${ }^{24} \mathrm{Nada}-$ lje, važno je da svi crteži koje autor prilaže kao osnovu ikonografskoj analizi nose pojašnjenje: crtež (prema originalu), prema fotografiji, ili crtež prema crtežu. Primijetili smo da se pojavljuju u stručnim publikacijama retuširane fotografije ili crtež na fotografiji, što, bez priložene kvalitetne fotografije kao jedinoga objektivnog dokumenta, nije prihvatliivo. Također nalazimo neprihvatljivim, ukoliko nije priložena dokumentarna fotografija, iscrtavanje kontura reljefa kredom prije fotografiranja. Jednostavno, kada govorimo o dokumentaciji, subjektivnost u viđenju ili tumačenju likovnoga prikaza na reljefima stećaka treba izbjeći. Digitalna fotografija, odnosno metoda suvremena, sofisticirana načina dokumentiranja o kojoj ćemo vjerujemo saznati više od kolega koji imaju praktično iskustvo, zasigurno je idealno rješenje. Do tada, pokušajmo dobiti što je moguće bolju i cjelovitiju dokumentaciju klasičnim načinom dokumentiranja.

Ustanoviti sve kriterije dokumentiranja stećaka, osobito je važno kada razmišljamo o neophodnoj i iznimno dobrodošloj pomoći zainteresiranih volontera. Bez organizirane suradnje s volonterima ili volonterskim udrugama, što podrazumijeva stručnu informiranost o spomenicima, vrstama kamena, vrstama mogućih oštećenja (mehaničkih i biokemijskih, dislokacije ili utonuća spomenika) i njihovu prepoznavanju i načelima njihova dokumentiranja (jednostavnim, usuglašenim vokabularom deskripcije), nemoguće je pratiti stanje očuvanosti enormnog broja stećaka. Ovakve organizirane udruge već postoje, imaju određeno iskustvo, te bi bilo dobro, a pod pokroviteljstvom neke od stručnih organizacija, razmijeniti i usuglasiti metode suradnje i rada.

Orijentacija spomenika ima iznimnu važnost. Na ovome shematskom crtežu (Sl. 1), za koji je kao primjer za prezentaciju uzet sljemenjak iz Bekavaca u Lovreću kod Imotskog, a prema tumačenju

24 O važnosti dokumentarne fotografije, na primjeru fotografskoga opusa Ćirila Ćire Raiča koji se čuva u Mostaru i važnosti jedinstvenoga dokumentarnog središta, I. Ribarević-Nikolić, nav. dj., str. 42-44. Lapsus calami u pisanju imena autora u citiranom radu ovdje korigiramo - Ćiril Ćiro Raič. 


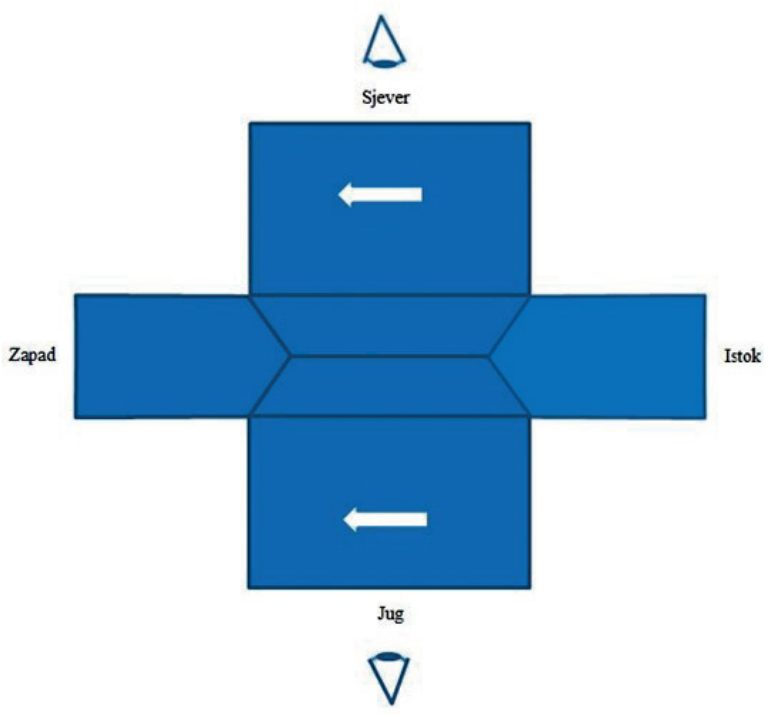

Slika 1. Shematski prikaz "otvorenoga plašta" sljemenjaka s naznakom smjera kretanja figura u nizu prema zapadu i s naznakom kuta gledanja

M. Wenzel. ${ }^{25} \mathrm{Na}$ dvjema stranama sljemenjaka isti je prikaz figura $\mathrm{u}$ nizu i pokretu u kompoziciji "Lovac slijedi jelena ili lov na jelena" gdje konjanik s kopljem u ruci slijedi jelena iznad kojega je prikazan predimenzionirani križ. ${ }^{26}$ Figure nisu u oprječnome nego u logičnome slijedu kretanja prema zapadu, iako idu slijeva nadesno na jednoj strani spomenika i zdesna nalijevo na drugoj strani ovoga sljemenjaka.

Na zapadnoj je strani prikaz dvostruke spirale iznad koje su tri križa Golgote (T. II., sl. 4). Tumačenje smjera kretanja figura u nizu na stećcima, sagledavajući smjer njihova kretanja u odnosu na orijentaciju stećka, može dovesti u pitanje logiku zapažanja o "naopakom" kretanju na primjeru plesača u kolu, čemu treba posvetiti dodatnu pozornost.

25 Marian Wenzel, Ukrasni motivi na stećcima, Ornamental motifs on Tombstaones from Medieval Bosnia and Surrounding Regions, Sarajevo, 1965., str. 398 gdje je dan tekstualni komentar i dvije table, T. 91, 14; T. 32, 17.

26 Čini se preciznijim deskriptivni naslov "lovac slijedi jelena" u odnosu na naslov "lov na jelena" kada su lovac i jelen u konfrontiranoj poziciji. 
Ivanka Ribarević-Nikolić - Interdisciplinarna metoda istraživanja...

Nadalje, predloženim načinom prezentacije "otvorenoga plašta" spomenika sagledive su, često prisutne, neukrašene strane jednoga spomenika, što je također važno u tumačenju cjelovita ikonografskoga ciklusa. Svemu navedenom dodajemo neophodnu paleografsku analizu, ukoliko natpis postoji, kako bi dokumentacija o jednome spomeniku bila cjelovita.

Jedino analiza svih motiva u kompoziciji, na svim stranama jednoga spomenika, uz pozornost datu orijentaciji, može dati zadovoljavajuće ikonografsko tumačenje cjelovita prikaza na spomeniku. ${ }^{27}$

Ovdje nije dan, također od iznimnoga ikonografskog značenja, grafički prikaz likovne kompozicije na kutovima gdje se sučeljavaju dvije plohe. Te rubne dodirne površine mogu nositi kompozicijski slijed figura u nizu, ili ponekad, jedinstveni motiv koji povezuje dvije strane spomenika. Može se vidjeti kraj niza figura u pokretu na jednoj plohi i njegov početak na susjednoj plohi, što vizualno zatvara ciklus kretanja iskazujući njegov slijed prikazan na svim stranama svijeta (!) i spomenika, ili gdje su kompozicije samostalni "ciklusi" na pojedinačnim plohama, često u izdvojenim registrima.

Stećak stoji slobodno u prostoru te su kinetički i vizualni doživljaj posjetitelja-promatrača u sprezi.

Nalazimo neophodnim konsultirati arhitekte i informatičare za navedeni grafički prikaz, podjednako kao i za prijedlog grafičkoga dokumentiranja složenijih oblika, poput križa. Svakako, prioritetna je razmjena mišljenja i suradnja na definiranju jedinstvene, elektronički pristupačne, grafičke dokumentarne osnove s kolegama koji se bave umjetnošću stećaka, bilo da je njihov rad usmjeren na konzervaciju, dokumentaciju, ikonografiju ili paleografiju.

\section{Dugo trajanje simbola i promjena njihova značenja u novom ikonografskom okružju: primjer spirale i kruga}

Simboli poput spirale i kruga zastupljeni su gotovo u svim kulturama od najranije povijesti. ${ }^{28}$ Njihova pojavnost u reljefnim kompozicijama stećaka, osobito kada govorimo o spirali, u znanstvenim osvrti-

27 Ponovo ukazujemo na primjer stećka iz Zgošće i rad Eme Mazrak, nav. dj., str. 140-195.

28 Jean Chevalier - Alain Gheebrant, Rječnik simbola, Zagreb, 1983., str. 320-324, 778-780; R. IvANČEviĆ, "Uvod u ikonologiju", str. 16. 
ma inicira principijelno dva problematska pitanja. Jedno je pitanje njihova podrijetla, a drugo je pitanje njihova značenja na reljefnim kompozicijama stećaka. Mi posvećujemo pozornost drugom pitanju. Ukazujemo, na malom broju odabranih primjera, da se simboli dugoga povijesnog trajanja, prilagođavaju idejnoj poruci i ikonografskom kontekstu vremena u kojemu jesu. Tema je vrlo sažeto prezentirana, imajući na umu zadatost ovoga članka.

Zanimljiv je prikaz tri patere u plitkom reljefu na žrtveniku Jana iz okolice Vrlike. Patera ili patela je plitka posuda bez drške koja se koristila kod prinošenja žrtve, prije svega vina, bogovima. Na vertikalnoj plohi ovoga žrtvenika patere su prikazane u pogledu odozgo, okrugle, ravne površine s ispupčenjem u sredini. Kako je naglašeno, Janov se kult štovao odvojeno od drugih božanstava, a August je oživio ovaj kult. ${ }^{29}$ Primjećujemo da su isti oblici, slični navedenim reljefima prikaza patera, znači krug s istaknutim kružnim središtem, nacrtani na zidovima ranokršćanske grobnice u Manastirinama, Salona. ${ }^{30}$ Ukazujemo na primjetne sličnosti prikazana oblika i uporabe patere na navedenu Janovu spomeniku, razmišljajući o mogućoj predstavi "kaleža", na isti shematizirani način u tehnici crteža, te njegova značenja u kršćanskome obredu euharistije. Navedenim razmišljanjima, usporedbom, možemo pridružiti isti oblik, kružnoga oboda i kružnoga središta plitke zdjelice - patena (plitica), na kojoj se čuva euharistijski kruh, a čiji prikaz susrećemo na slikama Posljednje večere. ${ }^{31}$ To bi nas nadalje moglo voditi prema prepoznavanju sličnih oblika na reljefima stećaka i njihova istovjetna značenja.

Dragim kamenom ukrašeni križevi crux gemmata, te intagliji s motivima poganske, rimskodobne ikonografije, prisutni su na mnogobrojnim relikvijarima i ne mijenjaju niti umanjuju vrijednost sa-

29 Mirjana Sanader, "Janov kult u Dalmaciji", u: Diadora, 30, Zadar, 2016., str. 137-138, sl. 12, spomenik koji se čuva u Arheološkom muzeju u Zadru, i registriran je pod brojem A-2475, datiran 121.-150. godine poslije Kr.

30 Duje Rendić-Miočević, Dalmatia christiana - Opera omnia, Zagreb - Split, 2011., str. 159-161, sl. 2. Tu vidimo "unutrašnji ukras grobnice smještene u istočnom dijelu probnih rovova izvedene u tehnici a pozzetto", gdje su nacrtani koncentrični krugovi, reklo bi se velikih dimenzija, prikazani na stropu, a prisutni su još neki stilizirani geometrijski motivi. Nismo uspjeli pronaći u literaturi detaljnije analize ovih crteža i njihove moguće analogije.

31 AnĐelko Badurina (ed.), "Euharistija", "Kalež", "Pričest", "Patena", u: Leksikon ikonografije, liturgike i simbolike zapadnog kršćanstva, Zagreb, 1979., str. 222-224, 313-317, 452, 482-483. 


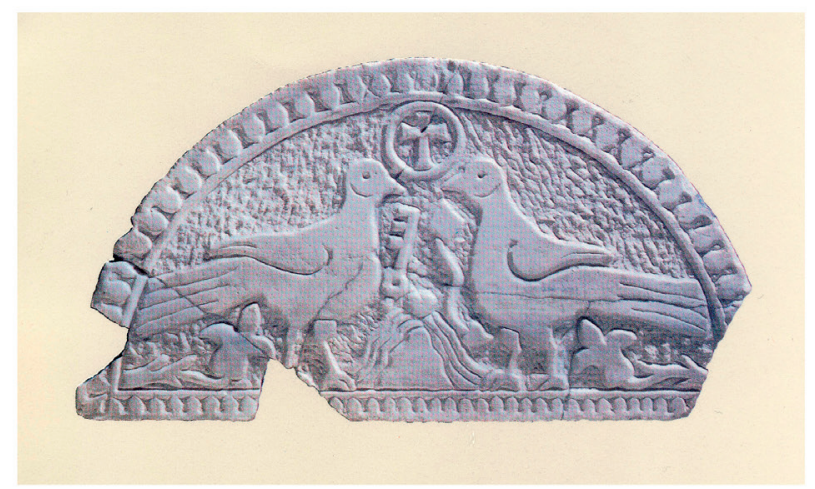

SI.1.

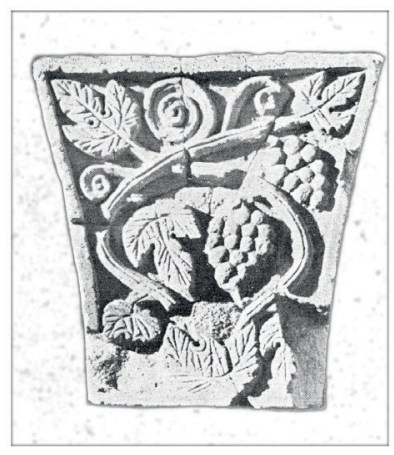

SI.2.

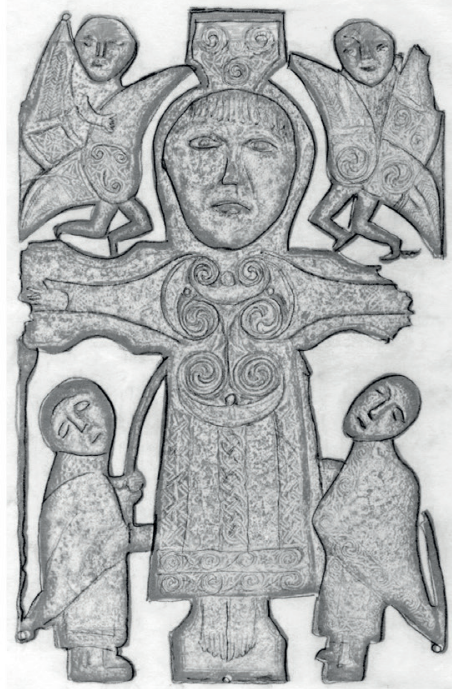

SI.3.

\section{Tabla I}

Tabla I.

Sl. 1. Luneta iz Gata s prikazom Uskrsnuća i Silaska u limb, prema: JASNA JELIČIćRAdONIĆ, Gata, Crkva Justinijanova doba, Split, 1994.

S1. 2. Lepenica, reljef na impostu, prema: ĐURo BASLER, Arhitektura kasnoantičkog doba u Bosni i Hercegovini, Sarajevo, 1972., str. 71. S1. 3. Raspeće, 8. st., pozlaćena bronca, National Museum of Ireland, Dublin (crtež prema fotografiji) 
kralnog značenja navedenih objekata. Ikonografski okvir i nadmoć postojećeg vjerovanja anulira prisutnost izvornoga značenja tih poganskih motiva. ${ }^{32}$

Poznati su prikazi listova, grozdova i spiralno savijenih grana vinove loze na impostima (T. I., sl. 2) i općenito u ranokršćanskoj kamenoj plastici, koju, napomenimo, srećemo na istim prostorima na kojima se razvija kultura stećaka. Isti motiv je također ikonografski vokabular antičkih poganskih spomenika, prihvaćen u ranokršćanskoj umjetnosti, sada s novim simboličkim značenjem ikonografije kršćanstva. Kompozicija križa spojena s lozom (T. II., sl. 7, 8) čini osnovu kršćanske ikonografije (Iv 15,1-5), te u istom kontekstu promatramo ikonografsku poruku ovih motiva na stećcima gdje forma ostaje ista, i ne mijenja se njezino ikonografsko značenje. ${ }^{33}$

Čuveni brončani reljefni ukras koji se čuva u Nacionalnom muzeju u Dablinu, potječe, kako se pretpostavlja, s korica neke knjige. Dan je prikaz Raspeća, datiran u 8. st. (T. I., sl. 3). Toraks, odnosno odjeća u razini grudnoga koša raspetoga Krista ukrašen je s tri para spirala. Krist je prikazan u odjeći. Figure dva anđela nalaze se lijevo i desno u razini Kristove glave, dok su figure rimskih vojnika u podnožju. Ističemo prikaze tri para spirala koje nose nesumnjivu poruku uskrsnuća. Primjećujemo da su rubovi odjeće prikazanih figura na ovome reljefu u bronci, ukrašeni spiralnim motivima. ${ }^{34}$

32 Gemma Sena Chiesa, "The Re-use of Mithological Cameos and Intaglios in Late Antiquity and the Early Middle Ages", u: Chris Entwistle, NoËL Adams (ed.), Gems of Heaven, Recent Research on Engraved Gemstones in Late Antiquity c. AD 200-600, London, 2011., str. 229-238, sl. 2, gdje je prikazan detalj freske iz 15. st. katedrale u Monzi, s prikazom scena iz života lombardske kraljice Teodolinde koja je živjela u 6.-7. st. Vidimo zlatare kako uzimaju dragi kamen iz antičke statue kako bi on bio ponovo korišten kao donacija za ukras nekoga liturgijskog objekta. Primjeri su mnogobrojni kada govorimo o gliptici, odnosno dragom kamenu, te stoga izneseno tumačenje nije jedini primjer. Tema zavrjeđuje interdisciplinarni (gemologija - arheologija - povijest umjetnosti) tematski osvrt, osobito kada razmišljamo o nasljedovanju antike i mogućem tumačenju simbolike dragoga kamena u srednjem vijeku.

33 M. Wenzel, nav. dj., str. 203; Đuro BAsLER, Arhitektura kasnoantičkog doba u Bosni i Hercegovini, Sarajevo, 1972., str. 63-151, sl. 85, Lepenica, reljef imposta prezentiran na T. I., sl. 2.

34 Peter Harrison, "The Bronze Crucifixion Plaque said to be from St. Johns (Rinnangan), near Athlone", u: The Journal of Irish Archaelogy II, 1984., str. 1-17, donosi prijedlog nešto drugačije datacije, ovoga najstarijeg poznatog pri- 
Ivanka Ribarević-Nikolić - Interdisciplinarna metoda istraživanja...

Ikonografija lunete iz Gata (Omiš, Hrvatska), nesumnjivo je najzanimljiviji ikonografski primjer, te mu posvećujemo nužnu pozornost. ${ }^{35}$

Na reljefnome prikazu lunete iz Gata, koja pripada crkvi Justinijanova doba (T. I., sl. 1), ukazujemo na primjer preuzimanja jednog antičkog simbola ("homerski" tip ključa prikazan zdesna uz golubicu, nasuprot prepoznatljivu Petrovu ključu) koji zadržava izvorno značenje simbolizirajući podzemni svijet. Tumačen na nov način u novom ikonografskom kontekstu ovoga kršćanskog spomenika, "homerski" tip ključa, sada simbolizira "Silazak u limb" (predvorje pakla), što je drugi način prikaza uskrsnuća. Petrov ključ, što je klasični oblik antičkoga ključa s prstenom i tri zupca na peru, otvara nebeska vrata, te je simbol kraljevstva nebeskog. Romb predstavlja kamen uklonjen s ulaza u grob, "odvaljen kamen s groba Kristova", u perspektivnom prikazu. U središtu kompozicije je brežuljak i hrid (simbol Crkve) odakle izviru iz jednoga izvora četiri rajske rijeke - četiri Evanđelja (četiri strane svijeta). Rijeke su simbol Krista, odnosno "žive vode" Kristova nauka. Na vrhu - križ u krugu simbol je Krista, golubice simboliziraju svete apostole Petra i Pavla, a dva ljiljana lijevo i desno ispod golubica ukazuju da je dan rajski prizor, kako to elaborira Jasna Jeličić-Radonić. ${ }^{36}$

kaza Raspeća u irskoj umjetnosti. https://www.jstor.org/stable/30001578_ (14. 2. 2020.); NANCY EDWARDS, "An Early group of crosses from the Kingdom of Ossory", u: The Journal of the Royal Society of Antiquaries of Ireland, 113, 1983., str. 9, donosi pregled repertoara spiralnog ornamenta i također izvrsni pregled ostalih ornamenata koji se sreću na monumentalnim križevima Irske, što može biti doprinos razmišljanju o pojavi i značenju monumentalnih križeva koje još uvijek na izvjestan način vežemo za umjetnost stećaka. https://www.jstor.org/stable/25508834_(14. 2. 2020.). Na tabli I., sl. 3 dali smo shematiziran crtež, prema fotografiji. Ovaj se brončani reljef može vidjeti na elektroničkoj adresi http://irisharchaeology.ie/2015/05/an-8th-century-crucifixion-plaque-from-co-roscommon/ (14. 2. 2020.); JEAN-Claude BonNE I DR., "Y a-t-il une lecture simbolique de l'ornement?", u: Perspective, 1/2010., str. 27-42. https://doi.org/10.4000/perspective1194 (14. 2. 2020.).

35 Jasna Jeličić-Radonić, Gata, Crkva Justinijanova doba, Split, 1994., str. 7178 i slika na str. 71 koju smo preuzeli (T. I., sl. 1).

36 Isto. Ističemo važnost analize ovoga iznimno važnog ikonografskog tumačenja, gdje je reduciranim simbolima, bez figurativnog prikaza, iskazana složena kompozicija "Uskrsnuća i Silaska u limb". Preporučamo studiranje cjelovita teksta iz kojega smo citirali samo zaključke. Autorica ističe i važnost slijeda čitanja simbola lunete kako bi oni mogli biti tumačeni u logičkome slijedu. 
Prikazana je osnovna ideja kršćanske religije na kojoj se temelji njezina doktrina - Uskrsnuće Kristovo. Uskrsnuće se prikazuje otkrićem praznog Kristova groba i paralelno silaskom u limb. U kasnijoj srednjovjekovnoj ikonografiji Zapada ova je tema zadržala dvojnost prikaza, dok se na Istoku uskrsnuće uvijek prikazuje silaskom u limb. Na reljefu iz Gata, kako je istaknuto u citiranom radu, tema uskrsnuća predočena je sintezom dviju odvojenih scena. Jedna je silazak u limb, koja je prikazana "homerskim" tipom ključa, neposredno povezana s temom praznog Kristova groba, "što je jedinstveni primjer prožimanja dvaju do sada ikonografski različitih prikaza, sadržajno vrlo bliskih". Nadalje, važno je istaknuti, "ranokršćanska ikonografija izražava ideju, a ne određeni događaj". ${ }^{37}$ Ukoliko se ponovo osvrnemo na prikazane ikonografske metode, istaknute na samom početku ovoga članka, vidjet ćemo da je ovaj idejni koncept prisutan u kontinuitetu tijekom trajanja kulture stećaka. ${ }^{38}$

Spomenimo i mozaičku kompoziciju apside crkve sv. Klementa u Rimu (12. st.), a na koju ukazuje M. Wenzel, gdje u složenoj kompoziciji s glavnom temom Raspeća, prostor ispunjava pedeset spiralnih vitica akantusa, a dvanaest bijelih golubica simboliziraju apostole. ${ }^{39}$

Također na reduciranu broju odabranih stećaka vidliive su kompozicije u kojima spirala, zajedno s drugim simbolima daje nesumnjivo kršćansku poruku simbolike života, odnosno uskrsnuća, koja u daljnjem značenju kršćanske doktrine ukazuje na očekivani Kristov dolazak i uskrsnuće mrtvih (T. II.). Tema simbola spirale i općenito ikonografska analiza kompozicija s motivom spirale, zavrjeđuje znatno više prostora i tematski pristup. Zanimljiv je primjer gdje je bočna ploha spomenika "prazna" i završava bordurom valovitih grana sa svinutim trolistovima, što je varijacija spiralne forme (T. II., sl. 8). Ova kompozicija može imati vrlo specifično i složeno značenje,

37 Isto. Bez sumnje, odabirom ovoga ranokršćanskog reljefa, koji ima nesumnjivu povijesnu i ikonografsku važnost, želimo ukazati na neophodnost sveobuhvatna akademskog promišljanja u pristupu analizi, zasigurno simboličkih i alegorijskih ikonografskih poruka reljefnih prikaza na stećcima. Ukazujemo na neophodnost studiranja cjelovita teksta, gdje J. Jeličić Radonić tumači povijesnu transformaciju značenja pojedinih simbola i njihova prihvaćanja $u$ novom ikonografskom okviru.

38 R. IvAnČEvić, "Uvod u ikonologiju", str. 51-52.

39 Isto, str. 204; https://commons.wikimedia.org/wiki/File:Apsis_mosaic_San_ Clemente.jpg (14. 2. 2020.). 


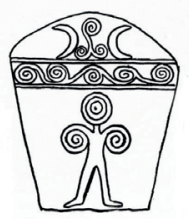

SI.1. Podvelež (Mostar)

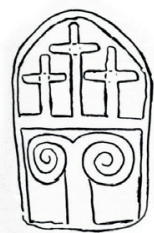

Sl.4. Lovreč, Bekavci (Imotski)

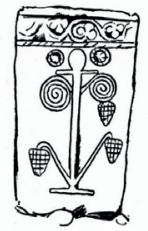

SI.7. Hodovo "Haremi" (Stolac)

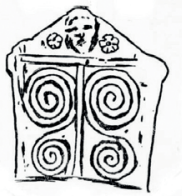

SI.10. Stupari (Kladanj)

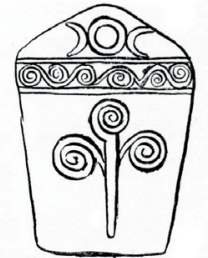

SI.2. Podvelež (Mostar)

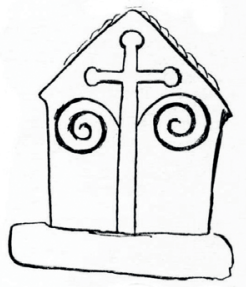

SI.5. Boganovići (Olovo)

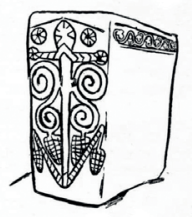

SI.8. Radimlja (Stolac)

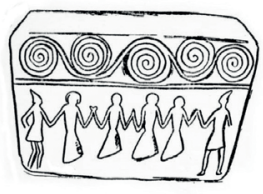

SI.11. Podvelež (Mostar)

Tabla II

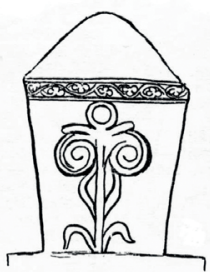

SI.3. Trnavica "Korkutovina" (Ulog)

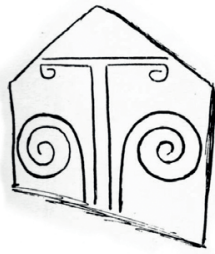

SI.6. Stupari (Kladanj)

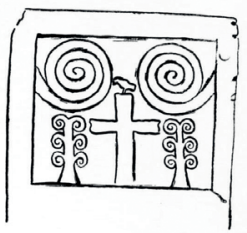

SI.9. Lađevine (Rogatica)

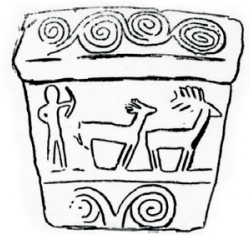

SI.12. Zagvozd, "Vukov Greb" (Imotski)

Tabla II.

Motiv spirale na stećcima, prema: MARIAN WENZEL, Ukrasni motivi na stećcima,

Sarajevo, 1965.

Sl. 1. (T. 30:3), Sl. 2, 3, 5 (T. 48:21, 20, 17), Sl. 4. (T. 32:17), Sl. 6. (T. 46:15), Sl. 7, 8 (T. 53:18, 15), Sl. 9 (T. 46:4), Sl. 10 (T. 80:14), Sl. 11 (T. 96:5), Sl. 12 (T. 110:3) 
kada se pojam značenja spirale "multiplicira", kada se spirala povezuje sa spiralno savijenim granama vinove loze ili drugim floralnim i nadalje s biljnim simbolima poput drveća. ${ }^{40}$

Može biti zanimljivo razmisliti o "popularnosti" ili većoj zastupljenosti određenih prikaza spirale, osobito kada ovaj motiv dominira kao ukrasni element ispunjavajući cjelovit prostor pojedinih strana nadgrobnika. To nadalje, kao što je prezentirano na navedenim primjerima, ne daje mogućnosti njegova drugačijeg ikonografskog tumačenja. ${ }^{41}$

Nada Miletić daje sažet pregled oblika spirala zastupljenih na stećcima, ističući da spirala, iako nije najviše rasprostranjen motiv, svakako jest brojčano najzastupljeniji. Nadalje, autorica ističe velik broj varijacija u kojima se javlja spirala, ukazujući i na kompozicije gdje se spirala pojavljuje u obliku koji "najavljuje figuru", kao u Podveležju (T. II., sl. 1), Dabrici (Stolac). ${ }^{42}$ Istaknimo i reljef na stećku iz Uloga (T. II., sl. 3), gdje specifična kombinacija simbola u osnovi egipatskog križa (crux ansata) i spirale čini iznimno ekspresivnom kompoziciju ovoga antropomorfnog prikaza.

Odabirom samo maloga broja spomenika (T. II., sl. 1-12) na kojima se javlja spirala, mi smo akcentirali pojavnost ovoga motiva s drugim ikonografskim prikazima poput različitih oblika križeva među kojima tri križa Golgote, tau križ, antropomorfni križevi, križ s pticom, s motivom vinove loze u kombinaciji s križem, uz portret, vjerojatno pokojnika (sl. 10), uz motiv kola (sl. 11) ili lova na jelene (sl. 12). Zasigurno da tematika nije iscrpljena. Neophodan je detaljniji osvrt na pitanja ikonografskoga značenja križa koji ne nosi figuru Krista ili figure raspetih na Golgoti u kombinaciji s ostalim motivima tipičnim za likovni vokabular stećaka, što ima nesumnjivu poruku biti kršćanskoga vjerovanja u uskrsnuće. Ova zanimljiva ikonografska tema zavrjeđuje detaljnu analizu kojom treba obuhvatiti cjelovitu deskripciju svih ploha navedenih spomenika.

40 Ittai Weinryb, "Living Matter: Materiality, Maker, and Ornament in the Middle Ages", u: Gesta, 52/2, 2013., str. 113-132. https://bard.academia.edu/ IttaiWeinryb (14. 2. 2020.).

41 Ovakvi su primjeri na stećcima u Križevićima (Olovo), Nabojine (Kladanj) te Varošište (Rogatica), prema: N. Miletić, Stećci, str. 58-59, sl. 78, 79, 56. Također ukazujemo na povijesni pregled razvoja i simbolike ovoga motiva u Radu M. Wenzel, nav. dj., str. 179-180, Table 41-51.

42 N. Miletić, Stećci, str. 59. 
Ivanka Ribarević-Nikolić - Interdisciplinarna metoda istraživanja...

\section{Ikonološko značenje arkada s potkovičastim lukovima: ma- nuskript Beatusova komentara Apokalipse kao predložak}

Prateći glavne smjernice načela o kopiranju i ujedno slijedeći zadatosti ikonografije, pokušavamo prepoznati pisani izvor i osobito važan likovni predložak određenoga motiva, u ovome segmentu istraživanja, arhitektonskog motiva arkada s potkovičastim lukovima, na primjerima stećaka na Radimlji.

Temi motiva potkovičastih lukova na stećcima dana je značajna pozornost u radovima $\mathrm{M}$. Wenzel i N. Miletić. ${ }^{43} \mathrm{U}$ iscrpnim analizama obje autorice ističu nekropolu na Radimlji kao primjer osobito dobro i pažljivo izrađenih ovih arhitektonskih motiva, koje M. Wenzel datira oko 1477. godine (T. III.). Primijećena je transformacija ovoga motiva, očitovana kako promjenama u kontaktu luka i arkade, tako i baze stupova u odnosu na korpus stupa. ${ }^{44}$

Za detaljnije zaključke potrebne su preciznije analize, gdje bi se sagledao odnos originala (mogućeg prototipa), modela, definiranjem njegova ishodišta, kopija i njihove prepoznatljivosti i rasprostranjenosti. Općenito, pa i na ovome primjeru, u tome procesu, primjetni su elementi "pojednostavljenja" forme, tako da u određenoj etapi produkcije, promjenom ili kombiniranjem različitih elemenata, model postaje exemplum. ${ }^{45}$

Umjetnička djela, rađena u različitim tehnikama, služila su kao prototip za izradu modela. Knjiga modela bila je zapravo način širenja i prijenosa umjetničkih ideja, jer je pristupačnost prototipu bila često limitirana. Knjige modela omogućavale su kopiranje. ${ }^{46}$ Kopija je mo-

43 M. Wenzel, Ukrasni motivi, table 17-22, str. 55-57; N. Miletić, Stećci, str. 4057; Gorčin Dizdar, The Standing Stones of Medieval Bosnia: Heresy, Dualism and Symbols in Pre-Ottoman Balkans (Dissertation), York University, Toronto, 2016., str. 261 ovaj motiv definira kao "antropomorfne niše".

44 Više prostora posvetili smo ovim promjenama u našem prethodnom radu, ukazujući s više preciznosti na iznesena mišljenja u literaturi. To je relativno rasprostranjen motiv koji se susreće i na križevima. Ostavili smo otvorenim pitanje zašto su upravo potkovičasti lukovi (a ne neki drugi), izabrani u datom vremenu i prostoru. U osvrtu koji slijedi u ovome članku pokušat ćemo ukazati na mogući odgovor, vidjeti: I. Ribarević-Nikolić, nav. dj., str. 61-63.

45 R. W. SCHeller, Exemplum, str. 41, exemplum je latinska riječ u značenju model.

46 Napomenimo da se u knjižnici Samostana sv. Lovre u Šibeniku čuva primjerak knjige modela MS.53, iz 1400. godine, o čemu donosi podatke uz bibliografiju R. W. SCHELler, Exemplum, str. 302. 


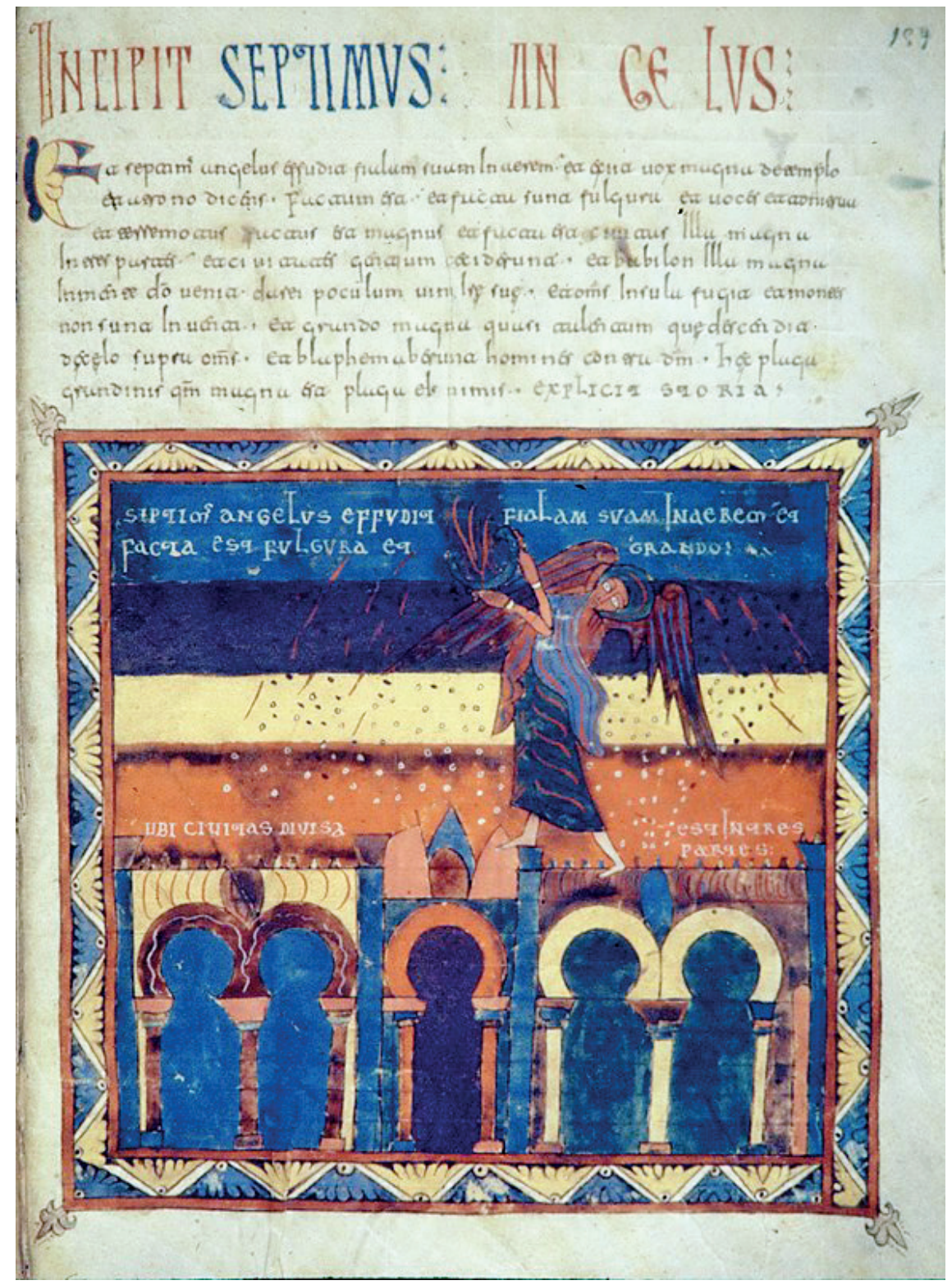

Slika 2. Valcavado Beatus f. 159r, "Sedma čaša Božjega gnjeva", 970. godina. (Credit, Wikimedia Commons) 


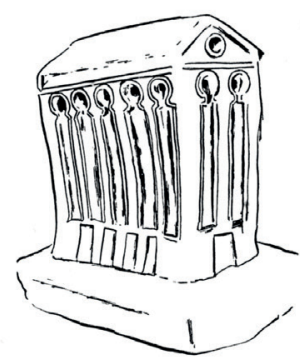

SI. 1

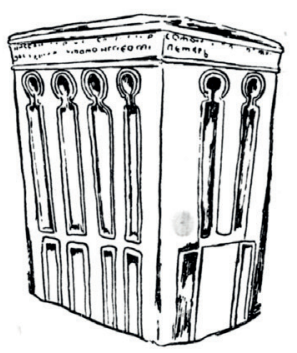

SI. 4

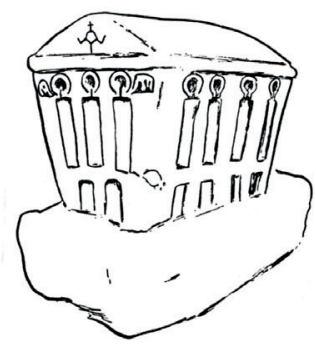

SI. 2

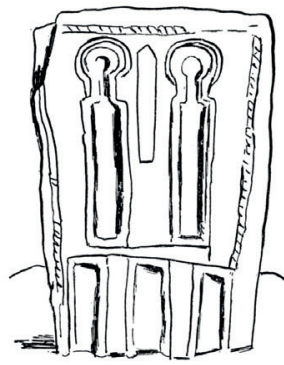

SI. 5

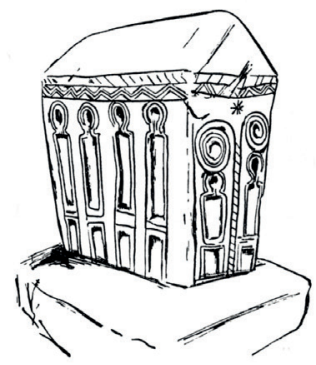

SI. 3

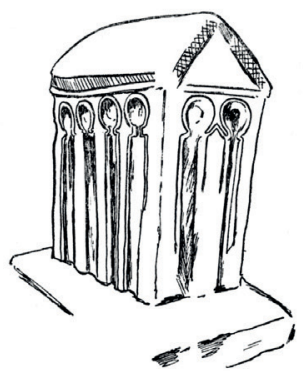

SI. 6

Tabla III

Tabla III.

Arkade s potkovičastim lukovima nekropole Radimlja Prema: M. Wenzel, Ukrasni motivi na stećcima, Sarajevo, 1965.

S1. 1-4 (T. 20:3, 10, 11, 12), S1. 5 (T. 21:5), S1. 6 (T. 91:2)

gla biti ciljno rađena tako da original bude prepoznat, ili je u procesu kopiranja umjetnik mijenjao osnovne elemente i kombinacijom različitih elemenata stvarao "kreativnu kopiju".47

Manuskript Beatusova komentara Apokalipse (Sl. 2), vjerojatno je predložak za motiv potkovičastih lukova (T. III.) na stećcima. ${ }^{48}$

47 S. Blick, "Exceptions to Krauthammer's Theory", str. 123-142; M. E. MüLlER, "The Use of Models in medieval Book Painting", str. XII govori o pojmovima "copy", "citation", "creative copy"; G. Dizdar, nav. dj., str. 262 koristi termin "hibrid".

$48 \mathrm{Na}$ slici 2 dat je prikaz kopije vjerne originalu Beatusova komentara Apokalipse, nastale 970. godine. Fotografiju je moguće vidjeti na elektroničkoj adresi 
Manuskript komentara Apokalipse, čiji je autor Beatus, svećenik iz Liebanae (Španjolska), nastao je u 8. stoljeću. Kopije vjerne originalu Beatusova manuskripta potječu iz kasnoga 9. stoljeća do prve polovice 13. stoljeća. ${ }^{49}$ Slikovni prilog, Valcavado Beatusa, kopija je vjerna originalu. Vidimo prikaz arhitekture s potkovičastim lukovima i temu Apokalipse "Sedma čaša Božjega gnjeva" (Otk 15,5-16,21), "Izljevanjem sedme čaše u zrak iz hrama, poviče jaki glas od prijestolja: 'Svršeno je!' Nato udare munje, potresi uzdrmaju zemlju, ruše se gradovi, ruše se gore, prolamaju se tuče..." ${ }^{\text {"0 }}$

U Beatusovu komentaru Apokalipse postoje višebrojni primjeri istog arhitektonskog prikaza arkada s potkovičastim lukovima, od kojih je osobito zanimljiv prikaz teme "Sedam crkava Azije", kojima je pismo, zapravo knjiga Apokalipse, upućeno. ${ }^{51}$ Pismo sedmorim crkvama u Maloj Aziji, pod "puninom simboličnog broja sedam podrazumijeva cijelo kršćanstvo koje trpi kušnje i progone (potkraj prvog stoljeća kršćanstva), te očekuje kraj ovoga svijeta i konačnicu u životu vječnom". ${ }^{52}$ Nema sumnje da potkovičasti lukovi na stećcima simboliziraju arhitekturu, i to sakralnu kršćansku.

Slijedeći načela teorije o kopiranju u srednjem vijeku, neophodno je analizirati i spomenute promjene primijećene na reljefnim prikazima ovih arkada na stećcima, kada luk postaje sve više sličan krugu i biva prikazan kao samostalan element kruga iznad pravokutnika arkade. Je li ovo produkt "transformacije" modela gdje je nakon višebrojnih kopija teško sagledati ishodišnu formu potkovičastog luka arkada, ukoliko se ovaj element analizira izvan konteksta prototipa - modela, ili je to svjesno kreiranje novoga oblika "kreativne kopije", pitanje je na koje treba naći odgovor. Također, upravo ovaj "novi" oblik, u usporedbi s nekim od tema Apokalipse Beatusovih stilskih i ikonografski "prepoznatljivih kopija", mogao bi nositi specifičnu tematsku poruku Apokalipse. Ove pretpostavke ostaju pitanja bez trenutačno

https://commons.wikimedia.org/wiki/File:Valcavado_Beatus_f._159r_-_Seventh_bowl.jpg. (14.2.2020.).

49 P. K. KLein, "The Role of Prototypes and Models: The Case of the Beatus Manuscripts", str. 2.

50 A. Badurina, "Apokalipsa", str. 125.

51 Michel Pastoreau - Gaston Duchet-Suchaux, La Bible et les Saints, Paris, 2017., str. 70-71 (Ap. 2-3).

52 A. BAdurina, "Apokalipsa", str. 120. 
Ivanka Ribarević-Nikolić - Interdisciplinarna metoda istraživanja...

mogućega zaključka, a duboko smo uvjereni, zavrjeđuje elaborirani rad u potrazi za odgovorom. ${ }^{53}$

Evidentna je istovjetnost forme potkovičastih lukova na prikazanoj kopiji Beatusova komentara Apokalipse i motiva arkada s potkovičastim lukovima na stećcima u Radimlji. ${ }^{54}$

Uspoređujući specifičan arhitektonski oblik potkovičastog luka ranih kopija manuskripta Beatusova komentara Apokalipse (Sl. 2), kakav je zabilježen na podneblju Španjolske gdje nastaje ovaj manuskript, primjećujemo istu formu potkovičastih lukova na reljefima arhitektonskih motiva arkada na stećcima Radimlje. To nadalje vodi ka zaključku da je Beatusov manuskript likovni predložak za motiv arkada s potkovičastim lukovima i ikonografsku temu Apokalipse.

Napominjemo da je izravna usporedba s likovnim predloškom Beatusova komentara apokalipse i tekstualnog iskaza višebrojnih tema apokalipse vezana za simboliku brojeva, čemu treba posvetiti pozornost kod ikonografske analize motiva arkada s potkovičastim lukovima. Komparacija reljefa na stećcima Radimlje s pojedinim prikazima ranih kopija Beatusa, gdje je kopija istovjetna originalu, mogla bi preciznije potvrditi naša opažanja u kontekstu složenoga ciklusa tema Apokalipse.

Mogu li izvjesne društveno-povijesne sličnosti vremena nastanka Beatusova manuskripta s prikazom specifičnog oblika (varijacija) potkovičastog luka koji je prisutan u sakralnoj kršćanskoj, ali i sakralnoj islamskoj arhitekturi na tlu Španjolske i vremena nastanka reljefnih arkada s lukovima istovjetnog potkovičastog oblika na stećcima Radimlje u periodu turskih osvajanja i prisustva islamske religije, biti poveznica za odabir upravo arkada s potkovičastim lukovima i za odabir teme Apokalipse, ostaje otvoreno hipotetsko pitanje!

Bez nakane i mogućnosti sagledavanja povijesti ove specifične forme potkovičastog luka ili, barem trenutačno, bez mogućnosti sagleda-

53 Za obradu ove teme neophodno je imati pristup cjelovitoj dokumentaciji stećaka koji nose reljefne prikaze motiva arkada s potkovičastim lukovima i njihovim "kreativnim kopijama" uz neophodno poznavanje ikonografije Apokalipse i uz neizostavnu konzultaciju ilustracija Beatusovih komentara Apokalipse. Preporučamo konzultirati katalog: J. Williams, Vision on the End in Medieval Spain, Catalogue of Illustrated Beatus, str. 1-293 (elektronička adresa dana je uz podnožnu bilješku br. 22).

54 Usporediti sl. 2, crteže na tabli III. i stećak vidljiv u drugom planu na tabli VI., sl. 1. 
vanja eventualne važnosti ovoga oblika, koji bi mogao inicirati odgovor na pitanje "zašto" je odabran upravo ovaj motiv, vidimo logiku odgovora u manuskriptu Beatusova komentara Apokalipse, kao likovnome i tekstualnome predlošku za motiv arkada s potkovičastim lukovima u ikonografskom kontekstu prikaza tema Apokalipse. ${ }^{55}$

Ova ideja, koja zahtijeva daljnja istraživanja, vjerujemo nudi mogućnost prepoznavanja još nekih specifičnih kompozicija Apokalipse. Ukazujemo na prikaze izdvojenih baza potkovičastih stupova prikazanih u formi pravokutnika u višebrojnim i brojčano različitim nizovima, koji moguće iskazuje temu "Krist među svijećama", odnosno "Krist među sedam zlatnih svijećnjaka", što prezentiramo kao otvoreno hipotetsko pitanje, pridruženo prethodnoj hipotezi.

\section{Ikonografija podignute desne ruke frontalno okrenuta dla- na s koncentričnim krugovima "vojvodskih figura" i samo- stalni motiv ruke s mačem}

Prethodno spomenuti arhitektonski motiv arkada s potkovičastim lukovima, prisutan na spomenicima s prikazom "vojvodskih figura", ali i na stećcima u neposrednoj blizini ove odabrane grupe od šest spomenika među kojima i jedan dječji nadgrobnik i osobito važan, veliki križ koji ujedno obilježava i kraj rasprostiranja nekropole. U ovome osvrtu bit će moguće posvetiti pozornost samo reljefnim kompozicijama stojećih figura ratnika s podignutom desnom rukom i koncentričnim krugovima (T. VI., sl. 1-6). Detaljna dokumentacija i ikonografska analiza arhitektonskih motiva arkada s potkovičastim lukovima, koje povezujemo s temama Apokalipse, svakako treba uslijediti kako bi ove jedinstvene kompozicije stojećih figura ratnika s podignutom desnom rukom i pridruženim koncentričnim krugovima, osobito ratnika s djecom (T. VI., sl. 1-3), bile cjelovito prezentirane.

55 Eduard Carbonell, "L'art wisigothique", u: Richard Medioni (ed.), La Méditerranée et l'art de Mahomet à Charlemagne, Paris, 2001., str. 61-67, gdje se autor osvrće na specifičnosti ovoga luka u kontekstu vizigotske i islamske arhitekture Španjolske. Prisustvo ovoga specifičnog potkovičastog oblika, a također i ovome obliku bliskog gljivastog oblika, pratimo kako u arhitekturi, tako i na stećcima. Podjednako ova je forma rabljena u reljefima rađenim $\mathrm{u}$ bjelokosti ili na emajlima Limogea, te ima dugu povijest i široku rasprostranjenost na prostorima kulture stećaka i znatno širem okružju Mediterana, što je nešto opširnije dotaknuto, uz citiranu literaturu N. Miletić i M. Wenzel, u našem ranijem radu, I. Ribarević-Nikolić, nav. dj., str. 61-63. 


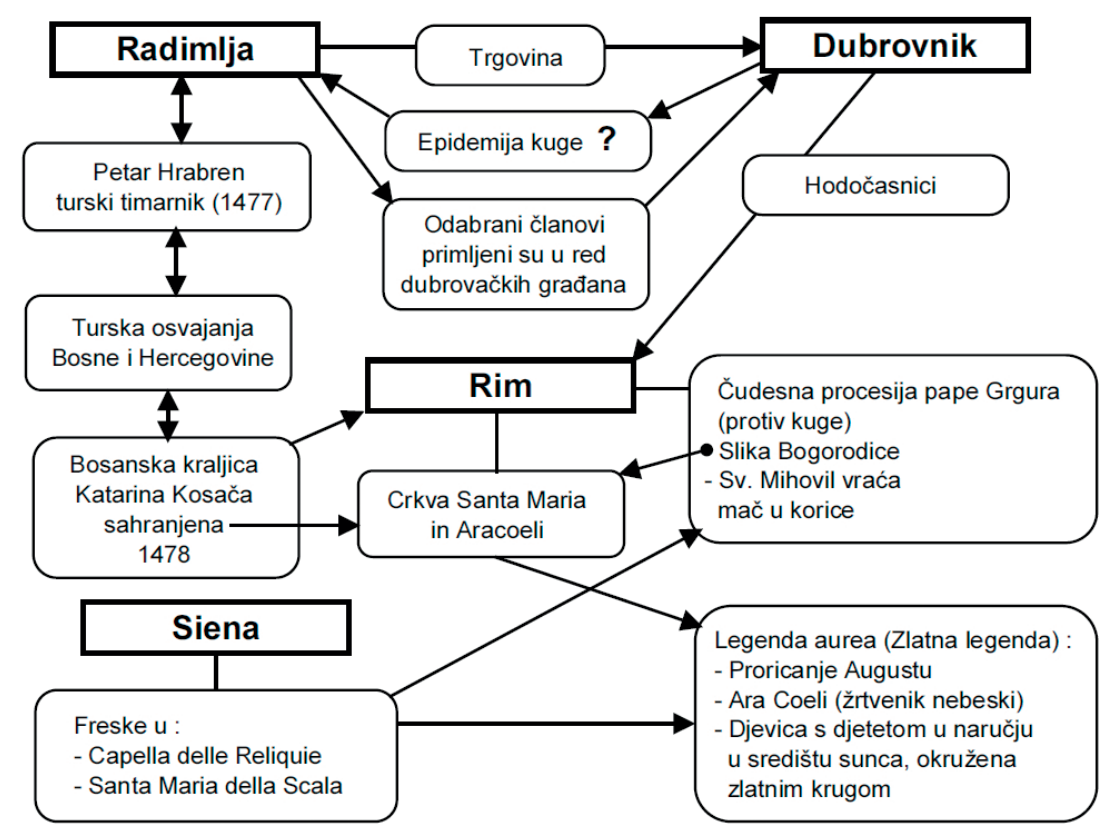

Razmišljanja i istraživanja : Ikonografija i ikonologija; Legenda aurea; teorija kopiranja; exemplum - knjiga modela; povijest medicinske službe u Dubrovniku (kuga); povijest.

Tabla IV

Tabla IV.

Grafički prikaz smjernica istraživanja ikonografije podignute desne ruke s koncentričnim krugovima "vojvodskih figura" na Radimlji i značenje samostalnoga motiva

ruke s mačem

Radeći na istraživanju ikonografije navedenih motiva bilo je moguće posvetiti pozornost i ukazati na značenje samostalnoga prikaza ruke $s$ mačem. Donekle složen, interdisciplinarni pristup u istraživanju ove teme, kojim se simbolički i neizravno povezuje Radimlja, Dubrovnik, Siena i Rim, grafički je prikazan na T. IV. ${ }^{56}$

Tumačenje ikonografskoga značenja podignute desne ruke frontalno okrenuta dlana s koncentričnim krugovima "vojvodskih figura" ratnika, akcentirano, ratnika s djecom, na stećcima Radimlje (Stolac),

56 Zahvaljujem Radoslavu Nikoliću, za obradu i elektroničku pripremu svih likovnih priloga u ovome radu, pridružujući i fotografije stećaka na Radimlji, s datumom fotografiranja srpanj 2016. 
osnovano je na postulatima dva, uvjetno rečeno, načela. To je, prije svega, metoda kreacije umjetničkoga djela u srednjem vijeku kopiranjem i posredstvom knjige modela, koja ima višestruko značenje. Nadalje, od velike je važnosti za razumijevanje medievalne umjetnosti, sagledavanje znatno širega religijskog i socijalnog aspekta vjerovanja u čudesnu moć relikvija i vjerovanje u zaštitnu moć svetaca iskazano u popularnoj zbirci "štiva o životu svetaca" poznatoj pod naslovom Legenda aurea ili Zlatna legenda.

Sagledavajući širi povijesni okvir kraja 15. stoljeća, kada vjerojatno nastaju stećci koje opisujemo (T. VI.), a koji pripadaju obitelji Hrabrena Miloradovića, ukazujemo na niz povijesnih okolnosti koje su mogle i vjerojatno jesu imale utjecaja na formiranje ikonografskog složenog znaka podignute desne ruke s pridruženim koncentričnim krugovima (T. V., sl. 3) i samostalnoga motiva ruke s mačem, koji se javlja na velikom broju nekropola.

Općenito politička nestabilnost, turska osvajanja, česte epidemije kuge, čije je jedno od žarišta bio Dubrovnik, ocrtavaju sliku vremena u širem zemljovidnom okružju Radimlje. Velikaši iz Radimlje imali su čvrste trgovinske veze s Dubrovnikom koji je i značajno ekonomsko, kulturno i religijsko središte. Mogućnost odlaska iz Dubrovnika brodom na hodočašće u Rim doprinosi zasigurno razmjeni materijalnih dobara i kulturnih strujanja na europskoj razini. ${ }^{57}$

Visoki društveni status "vlaške pravoslavne obitelji" ili u istom izvoru navedeno "vlaške obitelji" Hrabrena Miloradovića očitovani su odjećom i oružjem. Samo na jednom nadgrobniku nagovještene su portretne crte, u globalu uniformnog prikaza ovih figura, koje obilježavaju nadgrobnike muških članova. U cilju daljnjega pregleda, važno je naglasiti da su Hrabreni Miloradovići imali čvrste trgovačke veze s Dubrovnikom i značajan ekonomski status. U "osmanskom defteru iz 1477. godine spominje se vojvoda Petar Hrabren kao turski timarnik". Okvirno u istom periodu "nakon što se rotiše na svetom evangeliju božiem" primljen je vojvoda Petar Stjepanović-Hrabren zajedno s grupom bliskih uglednika Vukcem, Pavkom, Stipanom i Radivojem Popratovićem u red dubrovačkih građana. Radosav Hrabren sahranjen je 1505. godine u crkvi u obližnjemu selu Ošanići. ${ }^{58}$

57 Z. Blažına Tomić, Kacamorti i kuga, str. 232.

58 D. Lovrenović, "Topografija stećaka u BiH - gradovi mrtvih", str. 142-143, odakle smo preuzeli sve povijesne podatke koje iznosimo o obitelji Hrabrena 
Ivanka Ribarević-Nikolić - Interdisciplinarna metoda istraživanja...

Ratnici-očevi s djecom prikazani su na tri spomenika od ukupno šest odabranih spomenika. Na križu velikih dimenzija je uz oca reljef djeteta vrlo rane dobi, na sljemenjaku su otac i sin koji također ima podignutu desnu ruku ali bez pridruženoga znaka krugova, a treći je prikaz na bočnoj strani visokog sanduka gdje je ratnik u stavu oranta $s$ dvije djevojčice. Ispod njegove desne podignute ruke s koncentričnim krugovima je mlađa djevojčica čije su ruke spojene na razini pojasa. Starija djevojčica je ispod očeve lijeve podignute ruke i čini se $s$ prikazanim koncentričnim krugovima. Grupiranost ovih nadgrobnika moguće ukazuje na relativno kratak period njihova nastanka. Istovjetnosti figuralnih prikaza reljefne kompozicije stojeće figure $s$ podignutom desnom rukom frontalno okrenuta dlana i pridruženih koncentričnih krugova, gdje samo jedan lik iskazuje izvjesne portretne karakteristike, ukazuje na specifičan odnos naručitelja, vjerojatno prethodnim odabirom obiteljski prepoznatliive kompozicije i umjetnika koji prenosi, kopira zadani model (T. VI.).

Obrađujući ovu temu i tražeći korijene tumačenja u umjetnosti, neizravno i simbolički povezujemo Radimlju, Dubrovnik, Sienu i Rim. Kao što smo istaknuli, Zlatna legenda i običaji vremena te specifičan odnos valorizacije originala, modela i kopije, kao i odnos naručitelja jednoga djela i umjetnika daju nam osnovu za navedena razmišljanja.

Knjige modela mogu nam dati važne informacije o umjetničkim djelima, ali u znatno širem kontekstu, knjige modela doprinose spoznajama o važnom odnosu između originala i kopije, ukazujući na prijenos i širenje različitih formi umjetničkoga izraza općenito u europskome srednjovjekovlju. Knjiga modela, odnosno crteži, određenoga subjekta (teme) aktualnoga umjetničkog djela, zapravo služi kao baza, omogućava umjetniku da korištenjem toga crteža realizira umjetnički rad u drugom materijalu ili sasvim različitoj tehni-

Miloradovića; Z. Blažına Tomić, Kacamorti i kuga, str. 59-60, ukazuje da su politički događaji u Bosni, nakon pogubljenja bosanskoga kralja Stjepana Tomaševića i pada Bosne pod tursku vlast 1463., ujedno vremenski istovjetni sa stalno prisutnom mogućnošću izbijanja epidemije kuge. Z. BLAžınA Tomić - V. Blažına, Expeling the Plague, str. 121-129 i podnožna bilješka 94, gdje je ukazano da je 13. ožujka 1483. Malo vijeće odlučilo da ne će više slati zaražene od kuge na otok Mrkan, gdje su bili izolirani, tako da se biskup Trebinjskomrkanske biskupije može vratiti na otok jer je prošla epidemija kuge. DAD, Acta Minoris Consilii, sv. 22, f. 79v. Navedeni podatci ukazuju na realnu mogućnost, ali ne dopuštaju tvrdnju da je epidemija kuge mogla imati odjeka na populaciju Radimlje. 

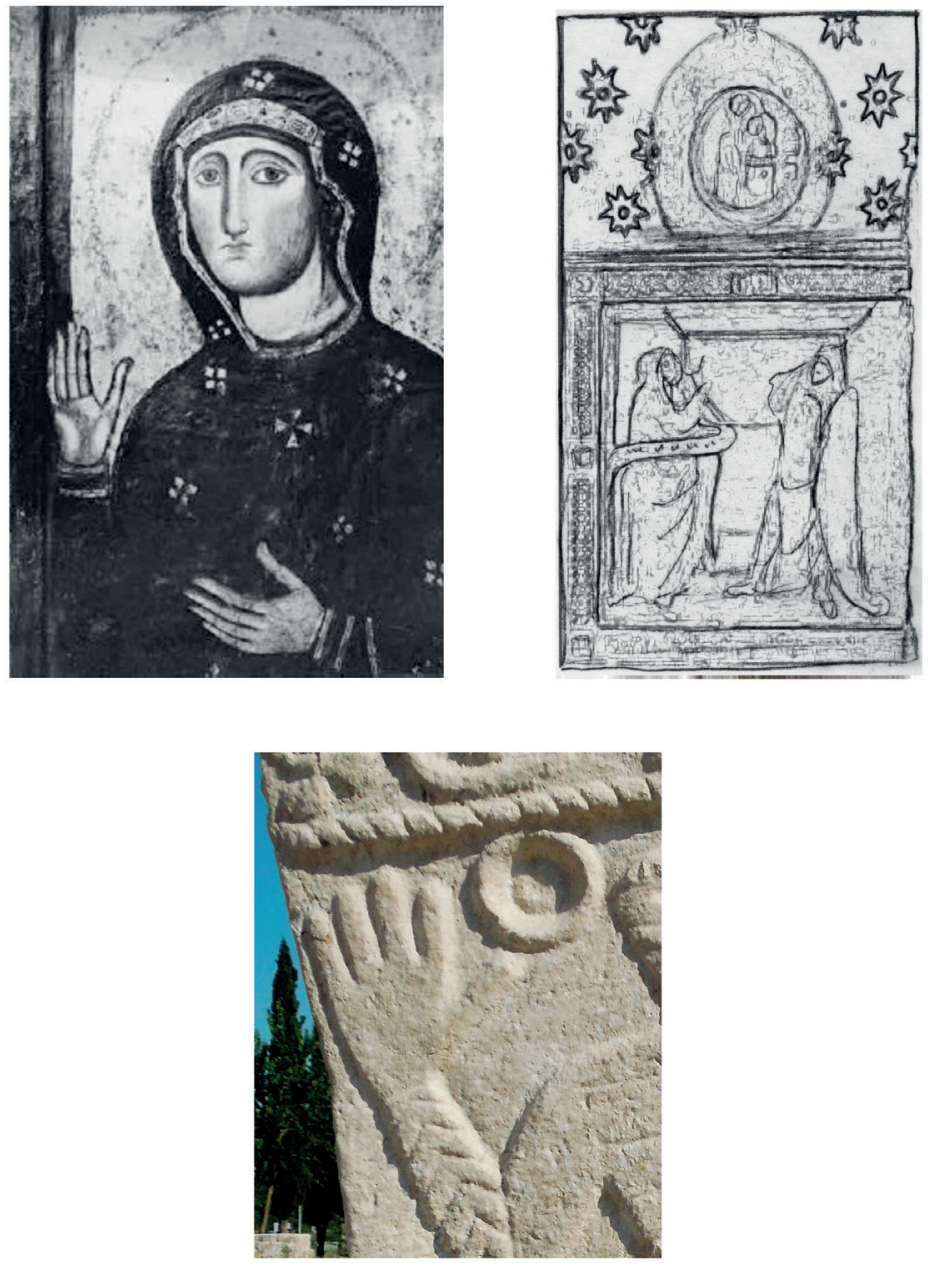

Tabla V

Tabla V.

S1. 1. Madonna di Santa Maria in Aracoeli, tempera na drvu, vjerojatno treća četvrtina 11. stoljeća, Rim (via Wikimedia Commons, Credits to Virgendelosremedios) S1. 2. Andrea Vanni, Imperator August i Sibila, freska, posljednja trećina 14. stoljeća, Compagnia di Santa Maria sotto le Volte, Santa Maria della Scala, Siena, crtež prema fotografiji,

Prema: Wolfgang Loseries, "Presentation of Relics in Late Medieval Siena, The Cappella delle Reliquie in Siena Cathedral", u: JAMEs Robinson - LLOYD DE BEER ANNA HARnden (ed.), Matter of Faith: An Interdisciplinary Study of Relics and Relic Veneration in Medieval Period, The British Museum, 2014., str. 63.

Sl. 3. Radimlja, desna podignuta ruka i koncentrični krugovi "vojvodske figure" (foto

R. Nikolić) 

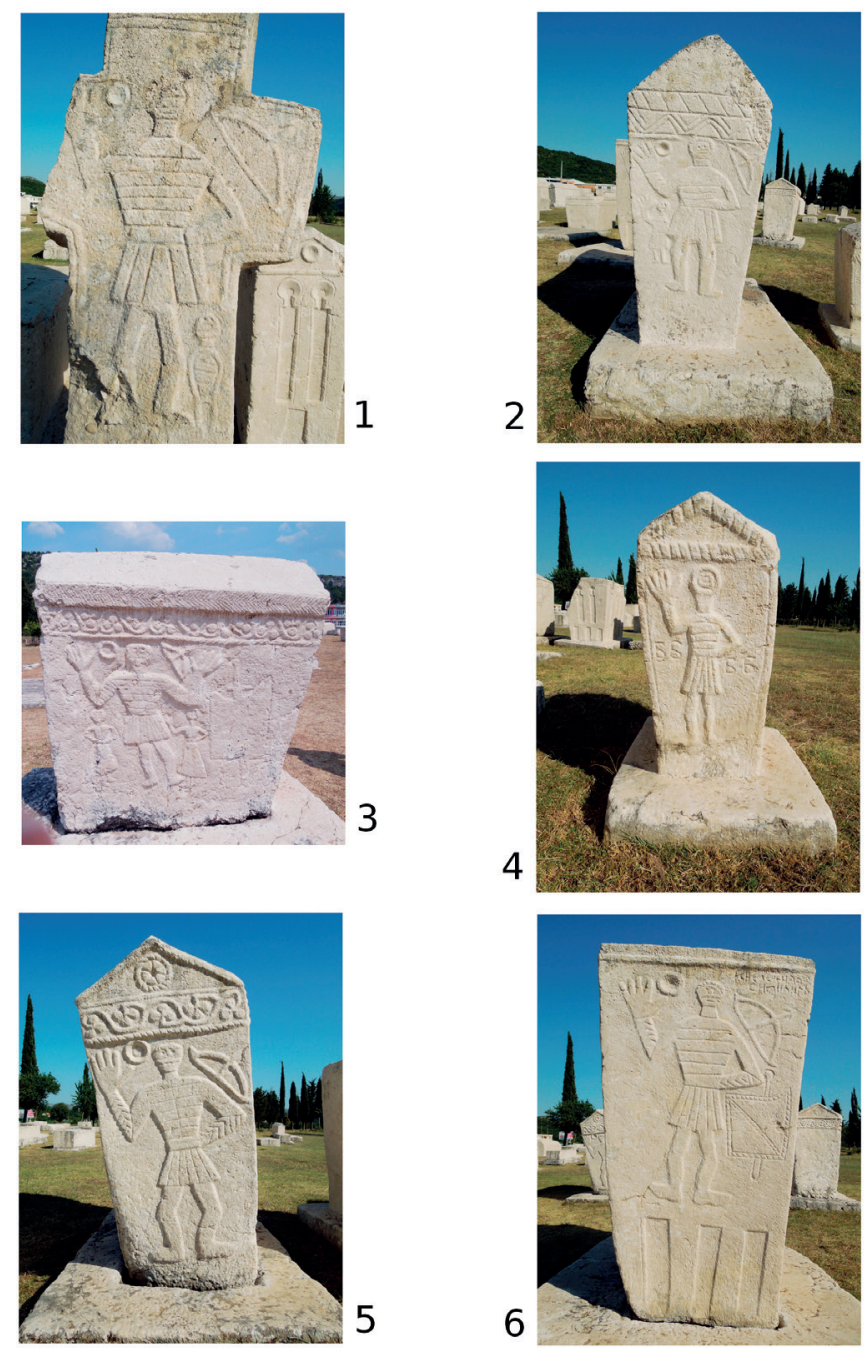

Tabla VI

Tabla VI.

"Vojvodske figure" nekropole Radimlja: Sl. 1-3 figure ratnika s djecom, Sl. 4 dječji nadgrobnik, Sl. 5, 6 figure ratnika 
ci. ${ }^{59}$ Tako knjige modela prenose ikonografiju i formalne likovne elemente "neovisno od prostorne i vremenske udaljenosti". Medievalni umjetnici, radeći u različitim materijalima i tehnikama, mogu imati pristup ovoj zajedničkoj "riznici" motiva i tema. ${ }^{60}$ Strogo poimanje kopije kao doslovne imitacije nije uvijek prioritetni cilj umjetnika. Stoga možemo govoriti o "kreativnoj kopiji" gdje medievalni umjetnik uzima slobodu "reinterpretacije" jednoga ili više modela. Ikonografski sadržaj i njegova tradicija u središtu su interesa medievalnog umjetnika, što znači da forma i vizualna realnost nisu prioritetni elementi koji se kopiraju. ${ }^{61}$ Ponekad original može biti prepoznat, ali istovremeno novi elementi mogu biti uvršteni "čineći kopiju mnogo izražajnijom u njezinome novom kontekstu". ${ }^{2}$

Ovaj osvrt na teoriju kopiranja u srednjem vijeku, akcentirano proces stvaranja "kreativne kopije", osnova je našemu razmišljanju i prezentiranom tumačenju simbola podignute desne ruke s pridruženim koncentričnim krugovima (T. V.) "vojvodskih figura" na Radimlji.

(Tabla V. i tabla VI.)

Hodočasnička središta bila su ishodišta kulturnih i religijskih strujanja i ujedno središta razmjene materijalnih dobara, osobito luksuznih proizvoda. Tako je Radimlja preko Dubrovnika, neizravno bila povezana s Rimom. Poput Rima i Siena je veliko hodočasničko središte i uz to grad posvećen Bogorodici - Civitas Virginis. Važnost relikvija i važnost votivnih darova kao opće obilježje europskoga srednjovjekovlja potvrđuje arhivski podatak iz 1359. kada je velika bolnica u Sieni, Santa Maria della Scala otkupila riznicu relikvija iz kolekcije "Bizantskog cara u Konstantinopolu" za ogromnu svotu od 3000 zlatnih florina. Zavjetni darovi imaju podjednako značenje. Upravo votivne freske u Sieni, oslikane početkom 15. stoljeća nakon prestanka kuge, tematski su vezane za događaje u Rimu i daju osnovu za daljnja razmišljanja u ovome poglavlju. U Rimu se čuva čudo-

59 R. W. SCheller, Exemplum, str. 2, 7.

60 S. BLICK, "Exceptions to Krauthammer's Theory", str. 126, bilješke 10-13, uz bibliografiju i komentare.

61 S. BLICK, nav. dj., str. 125, osvrće se na studije drugih autora, koji odjek čuvene Krauthaimerove teorije (iskazane u njegovu djelu "Introduction to an Iconography of Architecture" iz 1942. godine) kopiranja analiziraju kroz druge medije.

62 S. BLICK, nav. dj., str. 125-126, 129. 
Ivanka Ribarević-Nikolić - Interdisciplinarna metoda istraživanja...

tvorna slika Bogorodice, koja je prikazana bez djeteta s uzdignutom desnom rukom frontalno okrenuta dlana (T. V., sl. 1). Prema predaji, ovu sliku rađenu temperom na drvu, datiranu vjerojatno u treću četvrtinu 11. stoljeća, slikao je sv. Luka. Slika je poznata pod nazivom Madonna di Santa Maria in Aracoeli i čuva se u istoimenoj crkvi (pojasnimo, ara coeli znači nebeski oltar). ${ }^{63}$

U zavjetnoj procesiji protiv kuge, koju je papa Grgur I. Veliki organizirao u Rimu, nošena je upravo ova slika Bogorodice. Čudesno, kuga je nestala. Na Hadrijanovu mauzoleju viđen je arkanđel Mihovil u trenutku kada vraća mač u korice. Nakon ovoga čudesna događaja spomenuti objekt dobiva ime Castel Sant Angelo. ${ }^{64}$

Ukazujemo na gestu sv. Mihovila i položaj njegove desne ruke, ležerno savijene u laktu u trenutku kada vraća mač u korice, nakon što je kuga nadvladana. Ističemo izravne analogije prikaza na stećcima, motiva ruke prikazane cijelom duljinom od ramena, savijene u laktu ili samo podlaktice, ponekad s mačem. ${ }^{65}$

Prema tekstu Zlatne legende "Mihovil, hebrejski Mihael, znači, tko je kao Bog. Kad god se događa nešto što zahtijeva čudesnu moć, kako veli Grgur biva poslan Mihovil, kako bi se po samom činu i po imenu moglo zaključiti kako nitko ne može učiniti ono što može samo Bog. On će se, naime, kako svjedoči Daniel (usp. Otk 12,7-9), podići u vrijeme Antikristovo i stat će uz izabrane kao branitelj i zaštitnik". 66 Slijedeći ovo pojašnjenje i uspoređujući ikonografske prikaze navedenoga motiva, u kontekstu ostalih ikonografskih tema na istome spomeniku, mislimo da će mnogi prikazi na stećcima biti jasniji.

Crkva Santa Maria in Aracoeli u Rimu, u kojoj se čuva čudesna slika Bogorodice, Madonna di Santa Maria in Aracoeli, važna je u kon-

63 Wolfgang Loseries, "Presentation of Relics in Late Medieval Siena The Cappella delle Reliquie in Siena Cathedral", u: JAMEs RoBinson - Lloyd DE BeER - Anna Harnden (ed.), Matter of Faith: An Interdisciplinary Study of Relics and Relics Veneration in the Medieval Period, The British Museum, London, 2014., str. 56, 63, sl. 15.

64 W. Loseries, "Presentation of Relics in Late Medieval Siena", str. 61, sl. 13.

65 N. Miletić, Stećci, str. 91, sl. 53, prezentira primjer iz Lokvičića, Hrvatska, gdje je na frontalnoj strani sljemenjaka unutar jasno reljefno naglašena pravokutnoga kadra, prikaz ruke s mačem. U zoni zabata tri su križa Golgote. Ovaj motiv ruke s mačem je, prema I. Lovrenoviću, nav. dj., zastupljen na 27 nekropola istočne Hercegovine.

66 J. DE Voragine, Zlatna legenda ili Štiva o svecima, sv. 2, str. 261-263. 
tekstu općih povijesnih događanja na prostorima rasprostranjenosti stećaka. U crkvi Santa Maria in Aracoeli u Rimu sahranjena je bosanska kraljica Katarina Kosača 1478. godine. Prethodno, živjela je u Rimu gdje je došla bježeći pred turskim osvajanjima u kojima joj je otuđeno dvoje djece.

Čudesna procesija pape Grgura I. Velikog u Rimu, i pobjeda nad kugom, imala je veliku važnost u kršćanskome svijetu. Kao zavjetni dar, nakon prestanka kuge u Sieni 1411., prikazana je čudesna rimska procesija pape Grgura I. Velikog na fresci koju je slikao Benedetto di Bindo 1411.-1412. u Cappella delle Reliquie u Sienskoj katedrali. Na fresci je jasno vidljiva slika Madonne di Santa Maria in Aracoeli, što je potvrda da je upravo ovu, a ne neku drugu sliku Bogorodice slikao sv. Luka. Također jasno je vidljiv prikaz arkanđela Mihovila na vrhu Castel Sant Angelo, iako je freska znatno oštećena. ${ }^{67}$

Ističemo važnost fresko-prikaza prizora prema tekstu Legenda aurea, također prezentirana u dvije centralne sakralne građevine, Cappella delle Reliquie katedrale i Santa Maria della Scala bolnice u Sieni (T. V., sl. 2).

Dat je prikaz proricanja Sibile Imperatoru Augustu (T. V., sl. 2). Pretkazano je rođenje djeteta kojemu će se i sam car klanjati. "[...], o podne se oko sunca pojavi zlatni krug, a usred kruga na žrtveniku stajaše veoma lijepa djevica držeći dijete u naručju [...] ču se glas kako mu govoraše: Ovo je Ara Coeli, žrtvenik nebeski [...] a ovo je dijete veće od tebe i stoga mu se pokloni." ${ }^{16}$

Vidliivo na prezentiranim freskama, u središtu sunca (krug) Bogorodica je s Djetetom, okružena zlatnim krugom - gdje su sunce i zlatni krug prikazani kao koncentrični krugovi.

August je dao izgraditi "žrtvenik sina Boga živoga" na Kapitolu, gdje je viđeno ovo ukazanje, a prema tekstu Legenda aurea, to je upravo mjesto gdje je izgrađena crkva Santa Maria in Aracoeli u Rimu. ${ }^{69}$

Dva odvojena simbola, podignuta desna ruka Bogorodice zaštitnice od kuge (T. V., sl. 1), i simbol koncentričnih krugova s prikazom Bo-

67 W. Loseries, "Presentation of Relics in Late Medieval Siena", str. 56-58, sl. 13.

68 W. Loseries, nav. dj., str. 62-64, podnožna bilješka 40, 42, sl. 17, 18. Korišten je vokabular citiranoga hrvatskog prijevoda Jacobus de Voragine, Zlatna legenda, sv. 1, str. 49.

69 Claudia Bolgia, Reclaming the Roman Capitol: Santa Maria in Aracoeli from the Altar of Augustus to the Franciscans, c. 500-1450., New York, 2017. 
Ivanka Ribarević-Nikolić - Interdisciplinarna metoda istraživanja...

gorodice s Djetetom u središtu (T. V., sl. 2), spojeni su gradeći novi ikonografski znak (T. V., sl. 3). Ova "kreativna kopija" prezentirana je u tehnici reljefa na stećcima Radimlje. Na ovaj način prikazani novi ikonografski znak, "kreativna kopija", pretpostavljamo realizirana je, kako je to bilo uobičajeno, posredstvom "knjige modela".

Prema W. Loseries moguće je tumačenje teme čudesne procesije pape Grgura I. Velikog u Rimu, prikazane na freskama u Sieni u prenesenu značenju, gdje pobjeda nad kugom ujedno iskazuje želju za političkom i vjerskom stabilnošću i jakom jedinstvenom Crkvom u vremenu političkih i vjerskih previranja. ${ }^{70}$

Slično povijesno okružje, realna mogućnost širenja stalno prisutnih epidemija kuge i turska osvajanja ovih krajeva, susrećemo i u Bosni i Hercegovini u drugoj polovici ili krajem 15. stoljeća, kada nastaju spomenici s motivom podignute desne ruke frontalno okrenuta dlana s pridruženim koncentričnim krugovima vojvodskih figura ratnika i ratnika s djecom. Spomenici su locirani na periferiji nekropole čiji kraj obilježava veliki križ (T. VI., sl. 1).

Ne znamo jesu li djeca sahranjena zajedno s očevima, ili je prikaz djece na nadgrobnicima odraz molbe očeva da djeca budu zaštićena (od kuge).

Ovaj simbol složena kršćanskog ikonografskog značenja iskazan je jedinstvenim ikonografskim znakom podignute desne ruke i pridruženih koncentričnih krugova, što je, istaknimo još jednom, "kreativna kopija".

Primjećujemo da sve figure djece nemaju prikaz znaka koncentričnih krugova, te bi prisutstvo ovoga ikonografskog znaka moglo iskazivati razinu primljenoga kršćanskog sakramenta, vezanog za starosnu dob djeteta. Osobitu pozornost zavrjeđuje samostalni prikaz dječaka na stećku malih dimenzija (T. VI, sl. 4).

Neophodna su interdisciplinarna istraživanja. Jedino arheološka metoda istraživanja može dati odgovor o broju skeletnih ostataka očeva ili očeva s djecom, a antropološka forenzička analiza može ukazati na mogući uzrok smrti, što nadalje, može potvrditi neke od istaknutih pretpostavki.

$\mathrm{Na}$ osnovi u ovome članku predstavljenih analiza vidljivo je da odabrani motivi reljefa stećaka s nekropole Radimlja okvirno ukazuju 
na istovremenost trajanja ikonografskih načela "govora simbola i reduciranih scenskih prikaza", te zaključno, na reljefima "vojvodskih figura" ratnika s djecom vidimo "izraz okretanja realnosti gotičkog humanizma" pred kraj trajanja kulture stećaka.

\section{Zaključak}

Slijedeći metodske zahtjevnosti ikonološke analize, što je glavna tema ovoga članka, neminovno smo, uključujući i sadržajne odrednice precizirane $\mathrm{u}$ naslovu, $\mathrm{s}$ više ili manje pozornosti dotakli nekoliko problematskih pitanja neizostavnih u znanstvenom procesu istraživanja stećaka, što je članak učinilo strukturalno složenim. ${ }^{71}$

U opširnome uvodu posvetili smo nužnu pozornost pojašnjenju pojmovnog značenja, ciljevima i metodama ikonografske analize, na čijim postulatima, na odabranim primjerima, počivaju analize i razmišljanja iskazana u ovome članku. ${ }^{72} \mathrm{Da}$ bi takva cjelovita analiza mogla biti realizirana, posebna pozornost dana je dokumentaciji. Nije usamljeno ovdje osobito istaknuto mišljenje o važnosti dokumentacije i općenito o važnosti formiranja institucije u kojoj bi dokumentacija bila objedinjena na razini jedinstvene dokumentarne elektroničke platforme. Prijedlog načina dokumentiranja svih spomenika, prema unaprijed određenim zadatostima, shematski je prezentiran (Sl. 1). Ukazano je na nekoliko osnovnih dokumentarnih informacija koje bi okvirno mogle biti definirane kao tehničke (oblik, proporcije, orijentacija), grafičke (tekst, slikovni prikaz i mjesto njihove prezentacije na spomeniku) i neizostavna i osobito važna foto dokumentacija svih strana spomenika uz naznaku datuma fotografiranja. Svi navedeni elementi osnova su za cjelovitu ikonografsku

71 Zahvaljujemo anonimnom recenzentu na korisnim sugestijama, osobito naputku da pojasnimo teoretska načela i metode ikonografske analize, što zasigurno doprinosi jasnijoj prezentaciji pojedinih tema u ovome članku. Također, iznimno je dragocjen prijedlog da se segmenti hipoteza i istraživanja sažeto predstave u formi (ovoga) zaključka. Osobno nalazimo važnim ukazati na neke od znanstvenih radova koji su metodska ili idejna osnova za smjernice provedenih istraživanja, doprinos su našim zaključnim razmišljanjima ili su naputak produbljenim istraživanjima koja predstoje. U skraćenome obliku citirat ćemo ime autora i broj podnožne bilješke gdje je napisana cjelovita bibliografska jedinica (dalje u tekstu skraćeno kao bilj. uz pripadajući broj). Zahvaljujemo Uredništvu za mogućnost prezentacije ove problematike u predočenome opsegu.

72 M. Vicelja Matijašić, bilj. 1; R. Ivančević, bilj. 2. 
Ivanka Ribarević-Nikolić - Interdisciplinarna metoda istraživanja...

analizu iščitavanjem svih motiva, simbola, tematskih prikaza u kontekstu cjelovita likovnog prikaza reljefnih dekoracija, ili njihova izostanka, na svim stranama jednoga spomenika, osobito vodeći računa o orijentaciji spomenika. Pojedinim aspektima dokumentiranja posvećeno je više pozornosti, ističući neophodnost suradnje s arhitektima i informatičarima, uz poziv kolegama koji se bave istraživanjem stećaka da osobnim kritičkim osvrtom dopune iskazane prijedloge, kako bismo zajedničkim kooperativnim radom našli najbolje rješenje. Istaknuli smo, kao primjer cjelovite ikonografske analize, tematski članak posvećen stećku iz Zgošće, na kojemu su prepoznate teme Apokalipse. Također, u višebrojnim znanstvenim osvrtima iskazana je neophodnost topografskog dokumentiranja nekropola stećaka kao specifičnih spomeničkih cjelina, kako bi se sagledao povijesni arheološki krajobraz u kojemu su formirane nekropole stećaka. To bi ujedno omogućilo bolje razumijevanje pejzaža u prošlosti i suvremenoga pejzaža promatranih u kontekstu interakcije čovjeka i njegova prostornog okružja. ${ }^{73}$

Da bi razvoj umjetnosti na stećcima bilo moguće sagledati u kontinuitetu povijesnoga kulturnog okvira kako ranokršćanske, tako i srednjovjekovne umjetnosti, potrebno je imati pregledan i jednostavan pristup elektroničkom katalogu arhitektonske plastike (usporediti T. I., sl. 2 i T. II., sl. 7, 8). Detaljnije smo ukazali na važnost ove teme na primjerima ikonografske analize koje ćemo i ovdje spomenuti.

Podjednaka je važnost povijesnoga pregleda sakralne arhitekture koja je istovremena višestoljetnu trajanju kulture stećaka od njihova formiranja, procvata do nestanka. Napomenimo da je proces gašenja i nestanka kulture stećaka obilježen pojavom monumentalnih križeva (T. VI., sl. 1), koji nerijetko nose iste reljefne motive ili cjelovite kompozicije tipične za ikonografski vokabular stećaka. ${ }^{74}$

U istome kontekstu razmišljanja ukazali smo na nužnost prihvaćanja metode rada i ciljeva međunarodnoga projekta CARE - Corpus architecturae religiosae europeae (IV-X saec.), a ujedno smo akcentirali neke od izvanrednih rezultata recentnih revizionih arheoloških istraživanja medievalne sakralne arhitekture u Hercegovini. ${ }^{75}$

73 I. Alduk, bilj. 4; N. Miletić, bilj. 5; I. Ribarević-Nikolić, bilj. 3; E. Vučić, bilj. 12; E. Mazrak, bilj. 7.

74 N. Edwards, bilj. 34; M. Wenzel, bilj. 25.

75 M. Jurković - G. P. Brogiolo, bilj. 13; S. Vasilj, bilj. 14. 
Moramo naglasiti da natpisi na stećcima nisu obuhvaćeni ovom studijom iako neki od odabranih spomenika imaju epitafe. Citirali smo viđenje kojim je ukazano da epigrafski natpisi svjedoče o kanonskom kršćanskom određenju i ne nose indikacije dualizma. ${ }^{76}$ Ikonografska analiza koju smo proveli na odabranim primjerima može biti doprinos ovim zaključcima.

Nužna pozornost posvećena je, čini se rijetkim, tematskim osvrtima na astrološke motive na stećcima. Akcentirajući važnost studijskoga pristupa medievalnoj astrologiji, istaknuli smo ovdje neizostavnu interdisciplinarnu metodu istraživanja, gdje je poznavanje astrologije od bitne važnosti uz, također neophodno, poznavanje ikonografije. Takav način istraživanja zasigurno može doprinijeti našem razumijevanju poruke astroloških simbola, odnosno nebeskih tijela i načina njihove likovne i prostorne prezentacije na površinama stećaka, dajući nam naputke za njihovo prepoznavanje. ${ }^{77}$

$\mathrm{Na}$ reljefima stećaka prisutni su simboli, poput spirale i kruga, koji imaju dugu povijest trajanja. Citirajući zaključke povijesnih istraživanja i slijedeći metode ikonografskih studija u povijesti umjetnosti, poznato nam je da "izvori nekih oblika i kompozicija sežu u daleku prošlost i protežu se kroz više povijesnih slojeva, pa čak i međusobno nesnošljivih ili suprotnih kulturnih krugova. Tako korijeni kršćanske ikonografije, obilno crpe iz tla poganske ikonografije i to ne samo neposredno rimske, nego i grčke". ${ }^{78} \mathrm{Na}$ primjerima kruga i spirale, na nekoliko odabranih primjera (T. I., II.), odnosno spomenika različite datacije i provenijencije, ukazali smo na prisutstvo određenih "motiva dugoga trajanja" u kompozicijama izrazito kršćanske provenijencije u čijem ikonografskom okružju ovi motivi, neovisno o povijesnome ishodištu svojega nastanka, imaju simboličko značenje u kontekstu određenja ikonografije spomenika, odnosno vremena u kojemu spomenik nastaje, kao što je to pojašnjeno prethodnim citatom.

Opisno smo ukazali na reljefni prikaz plitke posude bez drške poznate pod imenom patela, ili patera, koja je služila za prinos žrtve u vinu. Tri patele prikazane su u pogledu odozgo na vertikalnoj strani Janova spomenika iz Vrlike (121.-150. poslije Krista), u plitkom reljefu kojim je istaknuta kružna forma i naglašeno kružno dno. Identi-

76 D. Lovrenović, bilj. 11.

77 K. Kužić, bilj. 9; P. J. Forshaw, bilj. 10.

78 R. Ivančević, bilj. 2; J. Chevallier - A. Gheebrant, bilj. 28. 
Ivanka Ribarević-Nikolić - Interdisciplinarna metoda istraživanja...

čan oblik, iskazan linearnim crtežom, prikazom kružne forme s akcentiranim središtem, nalazi se na zidovima ranokršćanske grobnice u Manastirinama (Salona), što je, moguće prikaz "kaleža", odnosno simbola euharistije. Navedenim razmišljanjima, usporedbom, možemo pridružiti isti oblik, kružnoga oboda i kružnoga središta plitke zdjelice - patena (plitica), na kojoj se čuva euharistijski kruh, a čiji prikaz srećemo na slikama Posljednje večere. Nadalje ukazano je na neophodnost analize sličnih oblika na stećcima, u mogućem značenju euharistije. Ovo razmišljanje zahtijeva produbljenu analizu na osnovi navedenih mogućih predložaka (exemplum) i sličnih motiva na stećcima. ${ }^{79}$

U članku je motivu spirale posvećena znatna pozornost. Na višebrojnim primjerima (T. I., sl. 2, 3; T. II., sl. 1-12), ukazujemo na spiralni motiv trostruke spiralne kompozicije na reljefnom prikazu Raspeća na vertikalnom završetku križa i figurama anđela, ali i spiralnih motiva ukomponiranih u dekorativne rubne elemente odjeće prikazanih figura, ovoga spomenika 8. stoljeća iz Irske (T. I., sl. 3). Nadalje spiralni floralni motivi grana vinove loze, akantusa i drveća, zavrjeđuju detaljnu studiju, kao i kompozicije gdje su spirale zajedno s prikazima različitih tipova križeva, ili gdje su spirale dominantni motiv pojedinih ploha spomenika. ${ }^{80}$ Odabirom primjera $s$ motivima spirale na stećcima, naglašavamo da je neophodno "čitati" motiv spirale u kontekstu cjelovite kompozicije, analizom svih strana spomenika, neovisno o razini ukrašenosti pojedinih ploha. Želimo istaknuti primjer gdje je bočna ploha spomenika "prazna" i završava bordurom valovitih grana sa svinutim trolistovima, što je varijacija spiralne forme (T. II., sl. 8, Radimlja). Ova kompozicija može imati vrlo specifično i složeno značenje, kada se pojam značenja spirale "multiplicira" kada se spirala povezuje sa spiralno savijenim granama vinove loze ili drugim floralnim i nadalje s biljnim simbolima poput lišća i drveća. Ova tema nije razvijena u članku i zahtijeva ozbiljnu, tematsku studiju, kojom se može, a na osnovi literature koju navodimo i usporedbom s motivima na stećcima, ukazati na dugo trajanje i povezivanje jednog "idejnog koncepta" grčke filozofije koji je prihvaćen i iskazan "materijaliziranim" simbolom u vremenu medieval-

79 M. Sanader, bilj. 29; D. Rendić-Miočević, bilj. 30; A. Badurina, bilj. 8; R. W. Scheller, bilj. 21.

80 M. Wenzel, bilj. 25; P. Harrison, bilj. 34; N. Edwards, bilj. 34; N. Miletić, bilj. 8; J.-C. Bonne i dr., bilj. 34. 
noga kršćanstva. U ovom kontekstu ponovo skrećemo pozornost na važnost citata koje smo prezentirali na početku ovoga poglavlja. ${ }^{81}$

Na primjeru lunete iz Gata (T. I., sl. 1) ističemo neophodnost sveobuhvatnog razmišljanja o mogućem značenju jednoga simbola na primjeru antičkoga znaka "Homerova ključa" koji simbolizira podzemni svijet. Osnovno značenje ovoga (podrijetlom poganskoga) simbola ostaje isto. U kršćanskoj ikonografskoj poruci kompozicije lunete iz crkve Justinijanova doba, "Homerov ključ" simbolizira sada Kristov silazak u limb (nad pakao, carstvo mrtvih), što je ikonografski simbol Uskrsnuća. Ističući važnost svih prikazanih simbola na ovom iznimnom spomeniku, ukazujemo i na drugačiji prikaz iste teme. Geometrijski oblik, romb, perspektivni je prikaz pravokutnoga kamena kojim je bio zatvoren Kristov grob. Pomaknuti kamen ukazuje na prazan grob, iskazujući na drugi način temu uskrsnuća. Da bi se razumjela poruka ovoga reljefa iskazana jezikom simbola koji "izražavaju jednu ideju, a ne događaj" potrebno je tumačiti likovne elemente ove kompozicije određenim slijedom. ${ }^{82} \mathrm{Na}$ isti način razmišljamo o značenju reljefnih kompozicija na stećcima. Spomenik stoji slobodno u prostoru, te su kretanje oko spomenika, odnosno kinetički doživljaj i istovremeni vizualni doživljaj, znači percepcija ili čitanje likovne poruke (a ponekad na isti način i tekstualne poruke) na svim stranama (svijeta) jednoga spomenika, u izravnoj sprezi. Slijed čitanja likovne poruke, odnosno njezino tumačenje, izravno je vezano za orijentaciju spomenika.

Osvrćući se veoma sažeto na ikonografske metode u povijesti umjetnosti, pozornost smo posvetili "govoru simbola" ranokršćanske umjetnosti i analogno, $\mathrm{u}$ ovome periodu formiranim "reduciranim scenama" koje postaju prevladavajuća odlika tipična za romaniku. U periodu koji slijedi "narativna metoda razvija se u gotici 13. i osobito 14. st., kao izraz gotičkog humanizma i okretanja k stvarnosti". Ovisno o povijesnim promjenama stilova, ponekad je primjetno postojanje dvije ili čak tri ikonografske metode, te "ona formirana najranije nastavlja se u sljedeću epohu, a u vladajućoj se javljaju elementi buduće". ${ }^{33}$

Prisutstvo ovoga kontinuiteta globalno možemo sagledati prateći ikonografski izričaj reljefnih kompozicija na stećcima u Radimlji.

81 I. Weinryb, bilj. 40; R. Ivančević, bilj. 2 .

82 J. Jeličić-Radonić, bilj. 35.

83 R. Ivančević, bilj. 2; Đ. Basler, bilj. 6. 
Ivanka Ribarević-Nikolić - Interdisciplinarna metoda istraživanja...

U ovome članku pozornost je dana izabranoj grupi spomenika gdje su prikazane stojeće figure ratnika s podignutom desnom rukom uz koju je prikazan simbol koncentričnih krugova. Ovi figuralni prikazi, poznati su pod nazivom "vojvodske figure". Mi osobito ukazujemo na reljefne kompozicije gdje su prikazane figure ratnika s djecom (T. VI.). Tipično za ovu grupu od šest spomenika, lociranih na periferiji nekropole, među kojima je jedan križ velikih dimenzija i jedan dječji nadgrobnik, jesu statusni simboli očitovani odjećom i oružjem. Samo na jednom nadgrobniku nagovještene su portretne crte, u cjelini uniformnog prikaza ovih figura, koje obilježavaju nadgrobnike muških članova "vlaške pravoslavne obitelji" (ili, u istom tekstu navedeno "vlaške obitelji") Hrabrena Miloradovića. ${ }^{84}$

Ratnici-očevi s djecom prikazani su na tri spomenika. Na križu velikih dimenzija je uz oca reljef djeteta vrlo rane dobi, na sljemenjaku su otac s dječakom koji također ima podignutu desnu ruku ali bez pridruženoga znaka krugova, a treći je prikaz na bočnoj strani visokoga sanduka gdje je ratnik u stavu oranta s dvije djevojčice. Ispod njegove desne podignute ruke s koncentričnim krugovima mlađa je djevojčica čije su ruke spojene na razini pojasa. Starija djevojčica je ispod očeve lijeve podignute ruke i čini se s prikazanim koncentričnim krugovima. Grupiranost ovih nadgrobnika moguće ukazuje na relativno kratak period njihova nastanka. Istovjetnosti figuralnih prikaza reljefne kompozicije stojeće figure s podignutom desnom rukom frontalno okrenuta dlana i pridruženih koncentričnih krugova, ukazuje na specifičan odnos naručitelja, vjerojatno prethodnim odabirom obiteljski prepoznatljive kompozicije i umjetnika koji prenosi, kopira zadani model. Primjećujemo da se uz navedenu kompoziciju, na istim spomenicima i na spomenicima u neposrednoj blizini pojavljuje motiv arkada s potkovičastim lukovima. Budući da ne posjedujemo detaljnu dokumentaciju s analizom svakoga od navedenih spomenika, uključujući i sve strane pojedinačnih spomenika, u ovome osvrtu zadržali smo se samo na ikonografskoj analizi simbola desne ruke i pridruženih koncentričnih krugova i mogućega značenja arhitektonskoga motiva arkada s potkovičastim lukovima.

U cilju jasnijega sagledavanja metode i logike našega istraživanja važno je naglasiti da su Hrabreni Miloradovići imali čvrste trgovačke veze s Dubrovnikom i značajan ekonomski status. U "osmanskom

84 D. Lovrenović, bilj. 18. 
defteru iz 1477. godine spominje se vojvoda Petar Hrabren kao turski timarnik". Okvirno u istom periodu "nakon što se rotiše na svetom evangeliju božiem" primljen je vojvoda Petar Stjepanović-Hrabren zajedno s grupom bliskih uglednika u red dubrovačkih građana. Radosav Hrabren je 1505. sahranjen u crkvi u nedalekom selu Ošanići. ${ }^{85}$

Društveno-povijesne prilike ovoga perioda, druge polovice i kraja 15. stoljeća, očitovane na prostoru kulture stećaka, obilježavaju turska osvajanja Bosne i Hercegovine i stalnu opasnost od epidemije kuge. Istovremeno hodočasničke veze Dubrovnika s Rimom koji je važno europsko hodočasničko središte doprinose kako razmjeni materijalnih dobara, tako i kulturnih strujanja. Kršćanska vjera i zavjetni darovi, koji su često znak zahvale za prestanak epidemije kuge, te važnost koja se pridaje relikvijama obilježavaju srednjovjekovlje Europe. ${ }^{86}$

Već spomenute prije svega trgovačke veze obitelji Hrabrena-Miloradovića s Dubrovnikom, vjerojatno su očitovane, neizravno, višesmjernim europskim kulturnim utjecajima prvenstveno preko Rima. Također moramo spomenuti da je Dubrovnik bio relativno često jedno od žarišnih područja epidemije kuge. Možemo pretpostaviti, ali ne možemo tvrditi, da je ova kužna bolest mogla imati utjecaja i na populaciju Radimlje. ${ }^{87}$

Vjerska i kulturna strujanja zapadnoeuropskoga srednjovjekovlja obilježava hagiografija Legenda aurea - Zlatna legenda ili Śtiva o svecima koju je sastavio Jacobus de Voragine u 13. stoljeću. Zlatna legenda postaje glavni izvor ikonografskih tema i "postaje temeljni tekstualni uzor i izvor za kasnija razdoblja". Knjiga postaje još popularnija u doba tiska. Izvornik je bio poznat na području rasprostranjenosti stećaka i znatno šire. ${ }^{88}$

Dva iznimna događaja, oba zabilježena u Zlatnoj legendi, prikazana su na freskama katedrale i bolnice u Sieni, ujedno su zavjetni dar nakon prestanka kuge 1411. godine. Važno je istaknuti da su ove likovne teme na freskama Siene vezane za događaje u Rimu, izravno

85 D. Lovrenović, bilj. 18.

86 Z. Blažina Tomić, bilj. 19; W. Loseries, bilj. 17; Ž. Čorak, bilj. 23.

87 D. Lovrenović, bilj. 18; Z. Blažina Tomić, bilj. 19; Z. Blažina Tomić - V. Blažina, bilj. 19.

88 Jacobus de Voragine (prijevod S. Pavić), bilj. 15; M. Grčić, bilj. 16; Ž. Čorak, bilj. 23; R. Ivančević, bilj. 2; W. Loseries, bilj. 17. 
Ivanka Ribarević-Nikolić - Interdisciplinarna metoda istraživanja...

za crkvu Santa Maria in Aracoeli. Naslikana je čuvena procesija koju je organizirao Grgur Veliki (6. stoljeće), u Rimu i u kojoj je nošena čudotvorna slika Bogorodice, Madonna di Santa Maria in Aracoeli, koju je prema predaji slikao sv. Luka. Bogorodica je prikazana bez djeteta, s podignutom desnom rukom frontalno okrenuta dlana (T. V., sl. 1). Kuga je nestala, a na Hadrijanovu mauzoleju, koji je kasnije nazvan Castel Sant Angelo, viđen je sv. Mihovil u trenutku kada desnom rukom, ležerno savijenom u laktu, vraća mač u korice.

Druga tema opisana u Zlatnoj legendi govori o Sibilinom proricanju Augustu kojemu je rečeno da će biti rođeno dijete kojemu se Car mora pokloniti. Prema proročanstvu, nad nebeskim oltarom, u središtu sunca, okružena zlatnim krugom, viđena je Djevica s djetetom u naručju (T. V., sl. 2). U Rimu, na Kapitolu, gdje je ovaj prizor viđen, podignuta je crkva Santa Maria in Aracoeli. ${ }^{89}$

Nadalje, važno je istaknuti da je u ovoj rimskoj crkvi 1478. godine sahranjena bosanska kraljica Katarina Kosača, kojoj je otuđeno dvoje djece tijekom turskih osvajanja Bosne (T. IV.).

Slijedeći načela teorije kopiranja u srednjem vijeku, posredstvom "knjige modela", tumačimo proces nastanka simbola desne podignute ruke, koncentričnih krugova i samostalnog motiva ruke s mačem.

Naglasimo, Zlatna legenda je tekstualni izvor navedenih ikonografskih tema, odnosno tekstualno je ishodište likovnoga prikaza navedenih fresaka u Sieni. Nadalje, upravo sienske freske, koje su zavjetni dar u znak zahvale za prestanak kuge, a posvećene su Bogorodici koja je zaštitnica Siene, opisuju događaje u Rimu. Opisani događaji, ujedno likovne teme navedenih fresaka, izravno su vezani za crkvu posvećenu Bogorodici, Svetoj Mariji od nebeskoga oltara - Santa Maria in Aracoeli, u kojoj je sahranjena Katarina Kosača. Stoga, sagledavajući i društveno-povijesni okvir vremena nastanka stećaka u Radimlji (T. IV.), prepoznajemo navedene freske u Sieni kao originalno likovno djelo koje je kopirano i koje je ikonografski i likovni predložak (exemplum), reljefnim prikazima "vojvodskih figura" na stećcima Radimlje (desna podignuta ruka, koncentrični krugovi i uz to motiv samostalne ruke $s$ mačem).$^{90}$

89 C. Bolgia, bilj. 20; W. Loseries, bilj. 17; Jacobus de Voragine (prijevod S. Pavić), bilj. 15.

90 R. W. Scheller, bilj. 21; S. Blick, bilj. 21; M. Muller, bilj. 21; P. K. Klein, bilj. 22; W. Loseries, bilj. 17. 
Dva neovisna motiva, podignuta desna ruka Bogorodice zagovornice i prikaz Djevice s djetetom u naručju u središtu sunca (krug) okružena zlatnim krugom, što je sažeto u oblik koncentričnih krugova, prikazani su kao jedinstveni simbol, "kreativna kopija", podignute desne ruke s pridruženim koncentričnim krugovima (T. V). Ovaj jedinstveni simbol vjere i molbe Bogorodici nosi ujedno duboku simboliku kršćanske doktrine vjerovanja.

Prikaz sv. Mihovila, u trenutku kada desnom rukom vraća mač u korice, na spomenutoj fresci procesije Grgura Velikog pretpostavljamo da je mogao biti prototip, odnosno originalno djelo koje je kopirano, a čiji je tekstualni izvor Legenda aurea. Selektivnim kopiranjem, što je bilo uobičajeno, kopirani su odabrani detalji jednoga umjetničkog djela (ruka s mačem) koji su nadalje, među umjetnicima prenošeni, razmjenjivani i čuvani kao zbirka crteža ili "knjiga modela". Tako formirani "modeli" nadalje su služili umjetnicima u procesu kreiranja novih umjetničkih djela u različitim, odabranim tehnikama i materijalima. Posredstvom "knjige modela" mogao je odabrani model-exemplum-predložak biti korišten za reljefni prikaz samostalnoga motiva ruke ležerno savijene u laktu, s mačem. Nadalje, ovisno o odluci naručitelja ili odluke umjetnika, ovaj isti model (ruka od ramena, savijena u laktu, s mačem) mogao je biti selektivno kopiran, tako da postaje "novi model" kojim se predstavlja samo segment ruke, ili samo podlaktica, ponekad s mačem. Ikonografsko značenje "samostalnog motiva ruke" na stećcima, jer smo prepoznali njegov tekstualni izvor - Zlatna legenda, i likovni predložak - freska u Sieni s temom čudesne procesije Grgura Velikog u Rimu, u znak molitve i zahvale za prestanak kuge (Benedetto di Bindo, 1411.-1412., freska u Cappella delle Reliquie, katedrale u Sieni), izravno vežemo za sv. Mihovila. Sažeto rečeno, sadržaj likovnoga prikaza čudesne procesije ukazuje da je na zagovor Bogorodice, Madonna di Santa Maria in Aracoeli, čija slika je nošena u procesiji, molitva za prestanak kuge uslišena, te je poslan sv. Mihovil koji je nadvladao kugu (te vraća krvavi mač u korice).

Prilagođeni stilskom izrazu tehnike plitkog reljefa i ikonografskom modelu "govora simbola" i "simboličke reducirane scene", koji u povijesti umjetnosti i osobito primjetno u umjetnosti stećaka imaju dugu tradiciju, tumačimo spomenuti simbol i značenje podignute desne ruke (Bogorodice zagovornice), prethodno opisana motiva koncentričnih krugova (proricanje Augustu i znak na nebu iznad nebeskog oltara) i samostalnog motiva ruke ponekad s mačem (sv. Mihovila). 
Ivanka Ribarević-Nikolić - Interdisciplinarna metoda istraživanja...

Nadalje, prema tekstu Zlatne legende, možemo arkanđela Mihovila povezati i s temom Apokalipse.

Samostalni motiv ruke s mačem susreće se na velikom broju spomenika i nekropola, te nam predstoji ikonografska analiza ovoga simbola, koji povezujemo sa sv. Mihovilom, u sklopu cjelovite ikonografske kompozicije svakoga od spomenika.

Osobito ukazujemo na važnost metodskog pristupa analizi reljefnih kompozicija na stećcima, gdje težimo otkrivanju tekstualnoga izvora jednoga motiva i nadalje identificiranje njegova likovnog predloška (originalno umjetničko djelo), te analizom (selektivnoga i kreativnoga kopiranja) procesa prenošenja "modela" posredstvom "knjige modela", pokušavamo pratiti (ponekad istu iako likovno različitu) ikonografsku poruku motiva na stećcima. ${ }^{91}$

Da bi ova ne uvijek jednostavna ili upitno moguća i nesumnjivo zahtjevna metoda analize mogla biti provedena, neophodno je imati cjelovitu dokumentaciju. Naglašavamo da je neophodna kvalitetna dokumentarna fotografija (bez retuša i bez iscrtavanja kontura reljefa kredom na stećku prije fotografiranja) što je objektivno viđenje reljefne kompozicije. Uz fotografiju crtež je iznimno važan dokument, uz pretpostavku da je rađen in situ. U izvjesnoj mjeri crtež može biti subjektivan ili sugestivan, te upravo $s$ toga treba biti komplementaran fotografiji. (Ukazujemo na primjer motiva arkada s potkovičastim lukovima na T. III. gdje treba usporediti sl. 5 i 6 . Motiv na sl. 6 klasificiran je kao "dvije figure".)

Još jedan motiv, prisutan na spomenicima s prikazom vojvodskih figura, ali i na stećcima u njihovoj neposrednoj blizini, jest arhitektonski motiv arkada s potkovičastim lukovima. Usporedbom reljefnih prikaza na stećcima Radimlje i prikaza arhitekture u manuskriptu Beatusova komentara Apokalipse (T. III., sl. 2) prepoznali smo ovaj manuskript kao vjerojatno najraniji predložak navedenih motiva arkada s potkovičastim lukovima, koje nadalje ikonografski vežemo uz teme apokalipse. ${ }^{92}$ Napominjemo da je izravna usporedba s likovnim predloškom Beatusova komentara Apokalipse i tekstualnoga iskaza višebrojnih tema apokalipse, vezana za simboliku brojeva, čemu treba posvetiti pozornost kod ikonografske analize motiva arkada $s$

91 R. W. Scheller, bilj. 21; S. Blick, bilj. 21; M. Muller, bilj. 21; W. Loseries, bilj. 17; Jacobus De Voragine (prijevod S. Pavić), bilj. 15; R. Ivančević, bilj. 2.

92 P. K. Klein bilješka 22; J. Williams - T. Martin, bilj. 22; R. Ivančević, bilj. 2. 
potkovičastim lukovima. Komparacija reljefa na stećcima Radimlje s pojedinim prikazima ranih kopija Beatusa, gdje je kopija istovjetna originalu, vjerujemo, potvrđuje naša opažanja (Sl. 2).

Buduća i neizostavna, cjelovita analiza reljefa na svim stranama spomenika obuhvaćenih ovim osvrtom, uz aplikaciju u ovome članku iznesenih zaključnih razmišljanja, ali i iznimno važne metode istraživanja, dat će, vjerujemo, jasnije viđenje poruke "znaka i njegova značenja, medija i komunikacije" kasnog 15. stoljeća na odabranim spomenicima nekropole u Radimlji i znatno šire. 


\section{Interdisciplinary research method, protection and presentation of stecaks in the context of iconological studies}

\section{Summary}

Process of researching stecaks, their protection, conservation, museological and educational presentation require agreed manner of documenting. Indication of the monument orientation has a great importance in the meaning interpretation of the artistic relief message on stecaks. Monument, stecak, stands freely in the space and visual and kinetic experience (moving and perception) of the monument visitors operate together.

Following the guidelines of iconography and iconology, we tried to perceive the meaning of symbols in the context of relief composition of stecaks and at the same time the role which the monument, or its artistic message had in the given time and space.

On the example of spiral, which is historically a motif of long lasting, considering the selected group of monuments, we described the process and adjustments of the symbols meaning in the new iconographic environment (T. I., T. II.).

Perceiving the historical-social framework within which one piece of art is created, applying the theory on copying and usage of model book, with data brought by Legenda aurea (Golden legend), book from the $13^{\text {th }}$ century (T. IV.), we tried to define iconographic meaning of the raised right hand with concentrated circles of "ducal figures" on the necropolis Radimlja near Stolac (T. V., T. VI.) and at the same time meaning of the independent motif of a hand with sword which we connect to St. Michael.

With contrastive analysis of the architecture illustrations in the manuscript of Beatus' comment of Apocalypse, we pointed out 
possible meaning of motifs of arcades with horseshoe arches ( $\mathrm{T}$. III., fig. 2).

All the above mentioned observations and conclusions should be confirmed by additional research on the larger group of monuments and through an interdisciplinary approach, where archaeology and forensic anthropology should be of primary importance.

Keywords: documentation; iconology; Radimlja; Golden legend; Beatus. 